fied, they offer some additional information when considered together with the sedimentological and mollusc records.

\section{Conclusive remarks on the Skagen Well}

In the description given above, the faunal record is the basis for understanding the climatic changes in the Skagen Well, supplemented by the observation on the changes in the sediments. However, the changes found during the Holocene are most likely to be connected with changes in facies, and here the changing depth is the most prominent agent, ending up with the last event represented by the depositional history of the Skagen Spit.

Based on the dating of the Holocene and the Late Weichselian, the descriptions have been given in terms of episodes. Especially the Holocene strata points to a development from deeper- to shallow-water facies from Preboreal to Subatlantic. In this development there appears to be a facies change that can be compared to the bottom communities as known from the Skagerrak-Kattegat region when going from the deeper-water communities of the present day, the so-called Maldane-Ophiura sarsi community, to the Venus community of the more shallow seas.

The mollusc assemblages in the Skagen sequence indicate a deeper-water facies during the Eemian, the Weichselian and the older Holocene in contrast to what hitherto was known in other parts of the Danish area during the Late Quaternary.

The Skagen Well has a record of the changing seas during the Late Quaternary, from the Eemian through the Weichselian (although only in parts) and the Holocene. For the first time within the Danish area, the full record of the marine environmental transition from the Late Pleistocene to the Holocene can be demonstrated on the basis of molluscs. However, not all the episodes known from the Skagen Well can be found in marine facies of the other regions, but thanks to the new records from the North Sea around the Jydske Rev area, a near to full Holocene marine record is at hand, including part of the Preboreal (Petersen 1998).

\title{
The environmental changes through time in the seven sectors based on the molluscan records
}

The recorded mollusc species within each area are given in Appendix 6. Regarding the environmental changes through time within the Danish realm, the seven sectors will be considered from the Eemian, starting in the south within the classical area where Forchhammer named the deposits the Cyprina clay.

\section{Eemian species sorted after climatic affinities}

\section{The Bælt Sea}

\author{
Age: Eemian \\ Climatic regions: asbl \\ Class Bivalvia \\ Subclass Heterodonta
}

\author{
Order Myoida \\ Mya truncata Linnaeus 1758 \\ Total for climatic regions asb. : 1 (1.7\%) \\ Climatic regions: .sb. \\ Class Bivalvia \\ Subclass Heterodonta \\ Order Veneroida \\ Arctica islandica (Linnaeus 1767) \\ Order Myoida \\ Zirfaea crispata (Linnaeus 1758) \\ Total for climatic regions .sb. : 2 (3.4\%) \\ Climatic regions: .sbl \\ Class Bivalvia \\ Subclass Pteriomorpha \\ Order Mytiloida \\ Mytilus edulis Linnaeus 1758 \\ Order Pterioida
}


Heteranomia squamula (Linnaeus 1758)

Subclass Heterodonta

Order Veneroida

Mysella bidentata (Montagu 1803)

Tellimya ferruginosa (Montagu 1803)

Spisula elliptica (Brown 1827)

Macoma balthica (Linnaeus 1758)

Total for climatic regions .sbl: 6 (10.2\%)

Climatic regions: ..bl

Class Gastropoda

Subclass Prosobranchia

Order Neotaenioglossa

Littorina littorea (Linnaeus 1758)

Hydrobia ulvae (Pennant 1777)

Rissoa inconspicua Alder 1844

Rissoa membranacea (J. Adams 1800)

Rissoa parva (da Costa 1779)

Caecum glabrum (Montagu 1803)

Bittium reticulatum (da Costa 1778)

Aporrhais pespelicani (Linnaeus 1758)

Order Heterogastropoda

Triphora adversa (Montagu 1803)

Epitonium clatbrus (Linnaeus 1758)

Order Neogastropoda

Hinia pygmaea (Lamarck 1822)

Hinia reticulata (Linnaeus 1758)

Subclass Heterobranchia

Order Heterostropha

Odostomia scalaris MacGillivray 1843

Chrysallida obtusa (Brown 1827)

Chrysallida spiralis (Montagu 1803)

Ebala nitidissima (Montagu 1803)

Turbonilla crenata (Brown 1827)

Turbonilla lactea (Linné 1758)

Subclass Opisthobranchia

Order Bullomorpha

Philine aperta (Linnaeus 1767)

Order Anaspidea

Retusa truncatula (Bruguière 1792)

Retusa umbilicata (Montagu 1803)

Akera bullata Müller 1776

Class Bivalvia

Subclass Palaeotaxodonta

Order Nuculoida Nucula nitidosa Winckworth 1930

Nucula sulcata (Bronn 1831)

Subclass Pteriomorpha

Order Mytiloida

Modiolula phaseolina (Philippi 1844)

Order Pterioida
Ostrea edulis Linnaeus 1758

Subclass Heterodonta

Order Veneroida

Lepton nitidum (Turton 1822)

Acanthocardia echinata (Linnaeus 1758)

Parvicardium exiguum (Gmelin 1791)

Cerastoderma edule (Linnaeus 1758)

Mactra stultorum (Linnaeus 1758)

Spisula subtruncata (da Costa 1778)

Ensis ensis (Linnaeus 1758)

Angulus tenuis (da Costa 1778)

Scrobicularia plana (da Costa 1778)

Abra alba (Wood 1802)

Abra prismatica (Montagu 1803)

Chamelea striatula (da Costa 1778)

Timoclea ovata (Pennant 1777)

Dosinia lincta (Montagu 1803)

Order Myoida

Corbula gibba (Olivi 1792)

Barnea candida (Linnaeus 1758)

Subclass Anomalodesmata

Order Pholadomyoida

Thracia phaseolina (Lamarck 1818)

Total for climatic regions ..bl: 43 (72.9\%)

Climatic regions: ...1

Class Gastropoda

Subclass Opisthobranchia

Order Bullomorpha

Haminoea navicula (da Costa 1778)

Class Bivalvia

Subclass Pteriomorpha

Order Mytiloida

Mytilaster solidus (Poli 1795)

Subclass Heterodonta

Order Veneroida

Lucinella divaricata (Linnaeus 1758)

Gastrana fragilis (Linnaeus 1758)

Abra segmentum (Récluz 1843)

Paphia senescens (Cocconi 1873)

Gouldia minima (Montagu 1803)

Total for climatic regions ...1: 7 (11.9\%)

Total for the Eemian Bælt Sea: 59 (23.9\%)

Fifty-nine species have been found in the Brelt Sea region during the Eemian, seven of which are found or have been, as is the case with Paphia aurea senescens, in the Lusitanian region. All of the Lusitanian species are found only in the Eemian deposits and represent species living in the shallow-water environ- 
ment. Mytilaster solidus is intertidal attached to rocks or algae, Abra segmentum is infralittoral on sandy mud, and Haminoea navicula found in Zostera beds in sheltered areas. The other three living species Lucinella divaricata, Gastrana fragilis and Gouldia minima are found from or just below the tidal zone and further out at different depths. Paphia aurea senescens may as well be regarded as a shallow-water species, considering the distribution of the other Tapes species. In this way the overall climatic characterising species of the Eemian in the Bæelt Sea area are connected with the shallow-water environment.

All the Boreo-Lusitanian species are known from the recent Danish fauna. This is by far the largest group of molluscs, with 43 species forming $72.9 \%$ of the Eemian Bælt Sea fauna. 33 species can be found in the tidal to shallow-water environment, while 11 species Epitonium clathrus, Ebala nitidissima, Turbonilla crenata, Retusa umbilicata, Akera bullata, Nucula nitidosa, Nucula sulcata, Lepton nitidum, Acanthocardia echinata, Phaxas pellucidus and Timoclea ovata - find their minimum depth, defined by Acanthocardia echinata, Phaxas pellucidus and Timoclea ovata, at $4 \mathrm{~m}$, and Epitonium clatbrus at $5 \mathrm{~m}$. So rather considering the maximum depth indicated by some of the shallow-water species, there must be two faunas, of which one is shallow out to a depth of a few metres and another for deeper water.

There are six species with a rather broad range from the Subarctic to the Lusitanian regions. Five of these species can be found in shallow water, including the intertidal zone, except Spisula elliptica, which occurs only at greater depth.

The eulittoral species Mytilus edulis has given name to the Mytilus beds found in the lower part of the marine Eemian deposits in the Bæelt Sea region, characterising the littoral deposits.

Only two species, Arctica islandica and Zirfaea crispata from the Bælt Sea region, have a Subarctic-Boreal distribution. The overall characteristic species for the Eemian Bælt Sea deposits - Arctica islandica - can be found from the intertidal zone to great depth, but in the inner recent Danish waters often at depths from 10 to $60 \mathrm{~m}$. In the Eemian this species characterises the clay deposited during the deeper-water facies. The other mainly Boreal species Zirfaea crispata has been found only in the upper part of the Tapes sand at Stensigmose (Madsen et al. 1908, p. 176) which fits well with the depth interval of this species from low tide to $7 \mathrm{~m}$.

Finally Mya truncata covers the Arctic, Subarctic, Boreal and Lusitanian regions down to the Bay of Bis- cay and can be found from the intertidal zone down to $75 \mathrm{~m}$, in Danish waters often between 10 and $20 \mathrm{~m}$.

Taken together, all the information from the abovementioned climatic groups indicates that the Bælt Sea deposits are represented by two facies. One in littoral/ infralittoral water not deeper than maximum $10 \mathrm{~m}$, and one at depths of more than $5 \mathrm{~m}$, and it is seen that all of the characteristic Eemian species within the Bælt Sea area are Lusitanian species connected with the shallow-water facies.

Fifteen mollusc species of the Eemian Bælt Sea fauna show by the region of lowest mean salinity they inhabit that the salinity of the Bælt Sea area must have been higher than present-day waters by up to 30-33\%0 (Sorgenfrei 1958, table 11). Here listed as mentioned by Nordmann (1928, pp. 79-81): 33\%o Circe minima (Gouldia minima), 31\%o Dosinia lincta, 33\%o Lepton nitidum, 33\% Mactra stultorum, 30\% Montacuta ferruginosa (Tellimya ferruginosa), 30\% Mytilus phaseolinus (Modiolula phaseolina), 33\%o Nucula sulcata, 31\%0 Syndosmya prismatica (Abra prismatica), 30\%0 Venus gallina (Chamelea striatula), 30\%o Parthenia interstincta (Chrysallida spiralis), 32\%o Rissoa parva, 30\% (Epitonium clatbrus), 33\%o Turbonilla lactea, and 30\% Turbonilla rufa (Turbonilla crenata).

In the recent bottom communities out in the Bælt Sea area, Macoma balthica is the overall characteristic mollusc occurring in all the samples from this region, in some cases being the only mollusc and in some cases together with others such as Mytilus edulis, Cerastoderma edule and Scrobicularia plana in shallow water and in places with a vegetation of gastropods like Littorina littorea, Littorina tenebrosa, Rissoa membranacea and Rissoa inconspicua (Petersen 1913). The littoral elements with Mytilus edulis are well documented in the Eemian deposits by the so-called Mytilus beds, together with the infaunal Paphia aurea senescens found in situ within the strata around the Mytilus beds or even down in the freshwater layers.

However, Macoma balthica is only found in the Tapes sands at Stensigmose in southern Jutland (Fig. 1) and not at the many other Bælt Sea localities (Nordmann 1908, 1928).

In the deeper-water community of today the $\mathrm{Ma}$ coma community is replaced by the Abra alba or Astarte communities (Petersen 1913). Here again the Eemian deposits differ on the leading species in that

Fig. 99. The Voderup Klint section on the island of Ærø with dislocated marine clays of Eemian age. 


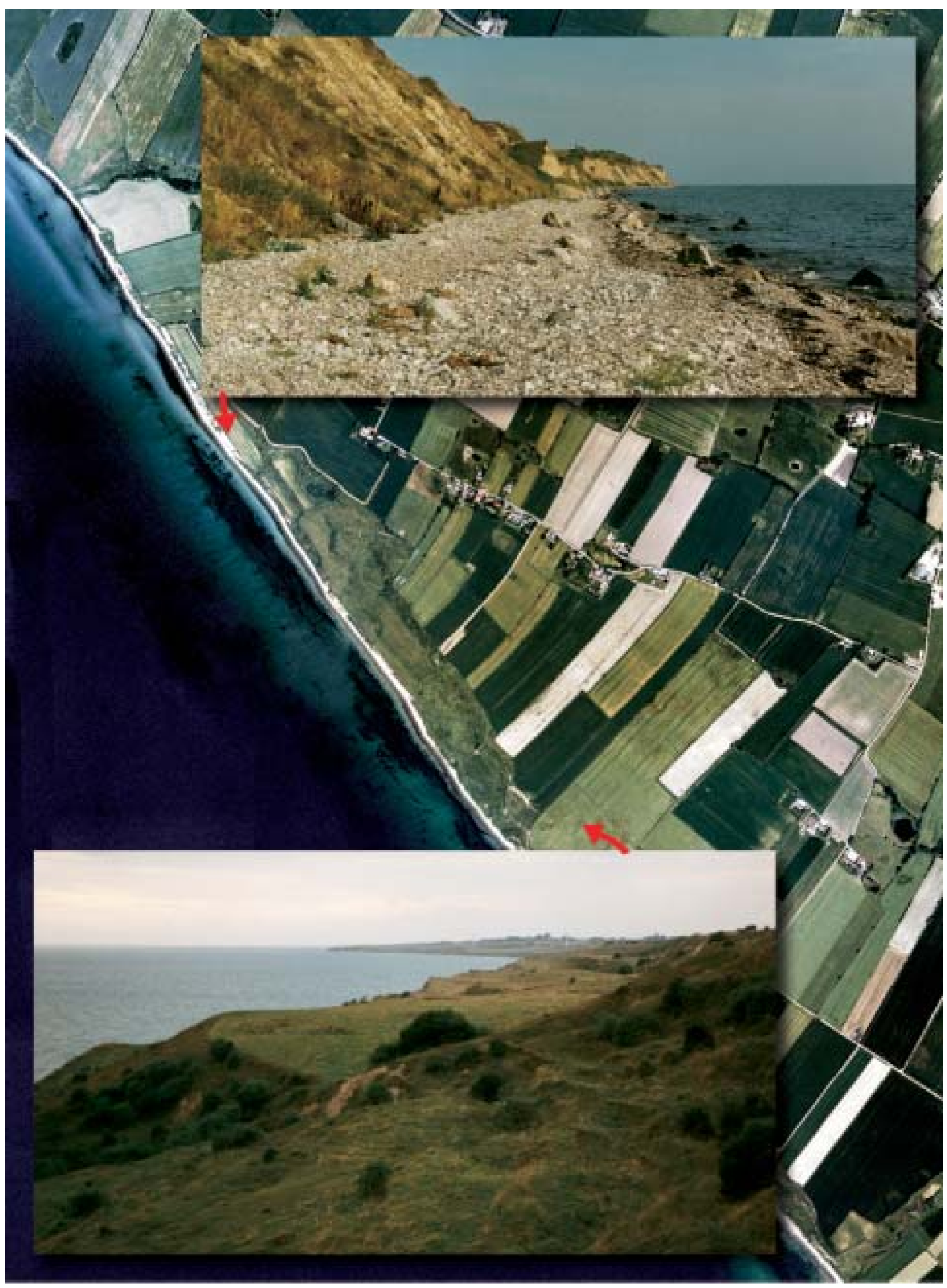


Abra alba is recorded only from Stensigmose and the Astartidae Tridonta borealis, Tridonta elliptica and Tridonta montagui have not been found at all in the Brelt Sea region or further to the east within the Baltic.

The characteristic species of the Eemian deeperwater deposits, the Cyprina clay (with an abundant number of Arctica islandica), is also present in the recent deeper water of the Bælt Sea, but Petersen (1913, p. 4) avoided using this bivalve as one of his characterising species in his 'Evaluation of the Sea' because of its uneven distribution, which is certainly not the case considering the present outcrops of the Cyprina clay along the shores of the Bælt Sea region (Figs 99, 100).

The great difference between the Eemian Bælt Sea fauna and the recent one which has been outlined above can be considered together with the concluding remarks of Nordmann (1908, pp. 113 and 148) on Cyprina islandica, stating that this species cannot be regarded as a characterising fossil species of the Eemian deposits, but more probably should be seen as a relict in the inner part of the Eemian waters from the sea, of a more Arctic-Boreal nature, so to say forming a parallel to the occurrences of the Astarte species in the present Bælt Sea and Baltic regions.

\section{The Baltic}

Age: Eemian

Climatic regions: asb.

Class Bivalvia

Subclass Heterodonta

Order Veneroida

Macoma calcarea (Gmelin 1791)

Total for climatic regions asb. : 1 (5.3\%)

Climatic regions: asbl

Class Bivalvia

Subclass Heterodonta

Order Myoida

Mya truncata Linnaeus 1758

Total for climatic regions asbl: 1 (5.3\%)

Climatic regions: .sb.

Class Bivalvia

Subclass Heterodonta

Order Veneroida

Arctica islandica (Linnaeus 1767)

Total for climatic regions .sb. : 1 (5.3\%)

\author{
Climatic regions: .sbl \\ Class Bivalvia \\ Subclass Pteriomorpha \\ Order Mytiloida \\ Mytilus edulis Linnaeus 1758 \\ Modiolus modiolus (Linnaeus 1758) \\ Subclass Heterodonta \\ Order Veneroida \\ Mysella bidentata (Montagu 1803) \\ Macoma balthica (Linnaeus 1758) \\ Total for climatic regions .sbl: 4 (21.1\%) \\ Climatic regions: ..bl \\ Class Gastropoda \\ Subclass Prosobranchia \\ Order Neotaenioglossa \\ Littorina littorea (Linnaeus 1758) \\ Hydrobia ulvae (Pennant 1777) \\ Turritella communis Risso 1826 \\ Aporrhais pespelicani (Linnaeus 1758) \\ Lunatia alderi (Forbes 1838) \\ Order Neogastropoda \\ Hinia reticulata (Linnaeus 1758) \\ Class Bivalvia \\ Subclass Palaeotaxodonta \\ Order Nuculoida \\ Nucula nitidosa Winckworth 1930 \\ Nucula nucleus (Linnaeus 1767) \\ Subclass Heterodonta \\ Order Veneroida \\ Cerastoderma edule (Linnaeus 1758) \\ Spisula subtruncata (da Costa 1778) \\ Scrobicularia plana (da Costa 1778) \\ Order Myoida \\ Corbula gibba (Olivi 1792)
}

Total for climatic regions ..bl: 12 (63.2\%)

Total for the Eemian Baltic: 19 (7.7\%)

The Baltic Sea fauna comprises only 19 species. However, five are new here compared to the Eemian known from the Bælt Sea area: three from the Boreo-Lusitanian climatic region, i.e. Turritella communis, Lunatia alderi and Nucula nucleus; one from the SubarcticLusitanian region, i.e. Modiolus modiolus; and one with an Arctic-Boreal distribution, i.e. Macoma calcarea. According to the living depth of Turritella communis

Fig. 100. One of the Cyprina clay outcrops along the Voderup Klint profile on the island of Ærø. 


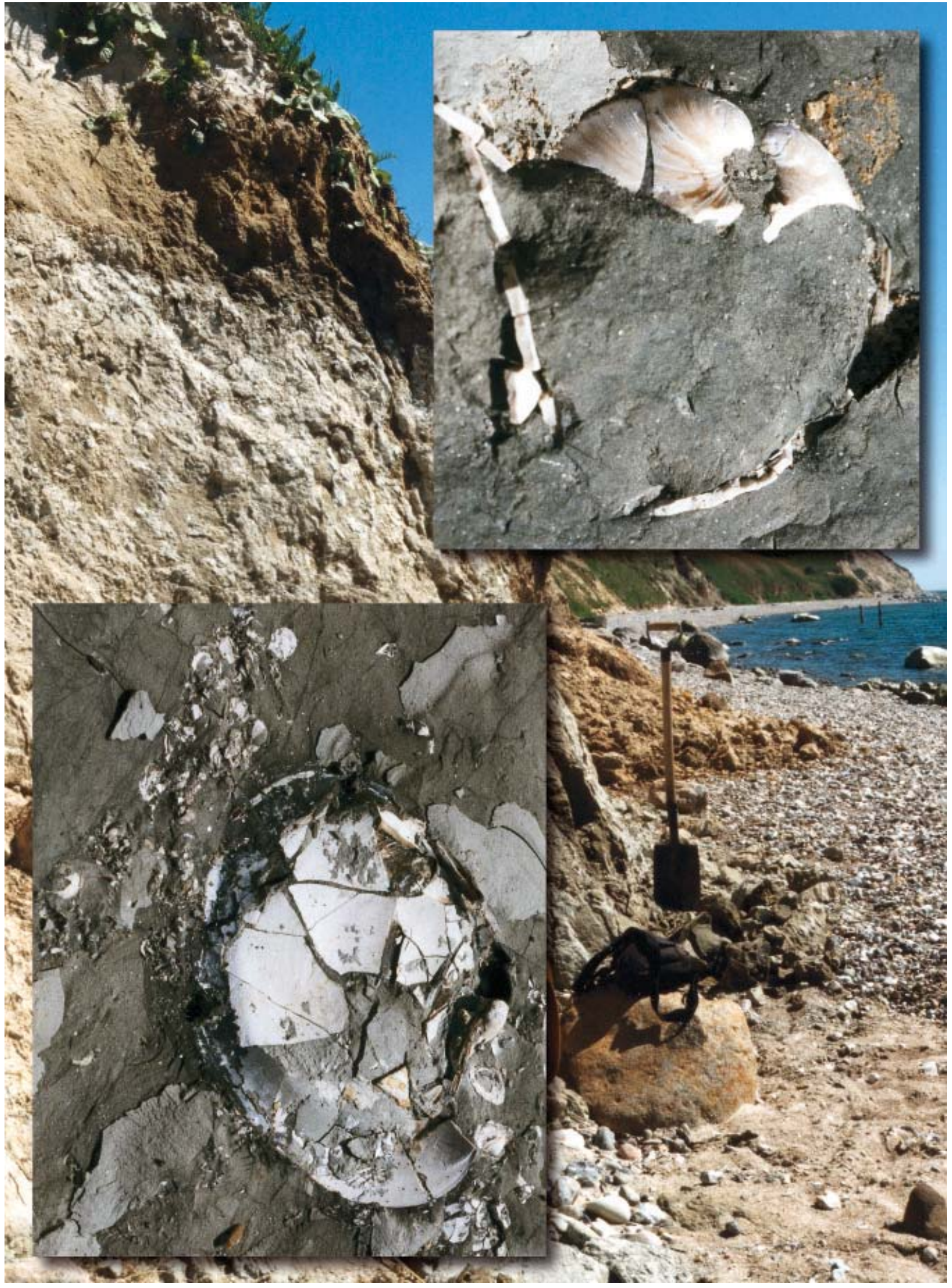


and Lunatia alderi, this should be an indication of environment deeper than $10 \mathrm{~m}$. But the eulittoral Mytilus edulis and Cerastoderma edule are nevertheless recorded from the Baltic Sea area, although these species do not come from layers in which they occur in great quantities in the Bælt Sea area (the Mytilus Beds).

From the climatic affinities of the molluscan finds in the Baltic Sea area, it appears that no pure Lusitanian species are found. This is the biggest contrast to the Bælt Sea region. it has also been the basis for keeping these finds apart, as done by Ødum (1933). However, considering the new element in this fauna, Turritella communis, compared to the Bælt Sea fauna, it has been argued by way of correlation on the basis of the Foraminifera that these deposits can be regarded as Eemian and that the facies belongs in deeper water than known from the Bælt Sea area (Petersen \& Konradi 1974).

Such deposits occur, besides that at Strandegaard Dyrehave, also at some places on Møn characterised by the occurrences of Turritella communis (Berthelsen et al. 1977).

In the region of lowest mean salinity inhabited (Sorgenfrei 1958, table 11), for 5 species from the Baltic during the Eemian, i.e. Modiolus modiolus, Turritella communis, Nucula nitidosa, Nucula nucleus, and Spisula subtruncata, a salinity between 20\% and 25\% can be shown, which is above the present conditions in the Baltic. However, this might be caused by a higher tide in inner Danish waters during the Eemian, in this way giving the same situation as known during the Atlantic, when the salinity was higher.

Unlike the situation in the Bælt Sea, the present-day characterising species Macoma balthica is recorded from the localities on Sjælland, Strandegaards Dyrehave and Møn.

The drop in number of species among bivalves and gastropods from the Bæelt Sea to the Baltic is from 45 to 11 species respectively in the present-day fauna (Sorgenfrei 1958), which is of the same order of magnitude as seen in the fossil fauna from the Bælt Sea to the Baltic during the Eemian. This means that in some way we have to do with the same basin structure/hydrographic situation, although the salinity was higher during the Eemian in the innermost Danish waters than at present.

\section{The Kattegat}

Age: Eemian

Climatic regions: asbl
Class Bivalvia
Subclass Heterodonta
Order Myoida
Hiatella arctica (Linnaeus 1758)

Climatic regions: .sbl

Class Gastropoda

Subclass Prosobranchia

Order Archaeogastropoda Scissurella crispata Fleming 1828

Order Neogastropoda

Buccinum undatum Linnaeus 1758

Class Bivalvia

Subclass Pteriomorpha

Order Mytiloida Mytilus edulis Linnaeus 1758

Total for climatic regions .sbl: 3 (9.4\%)

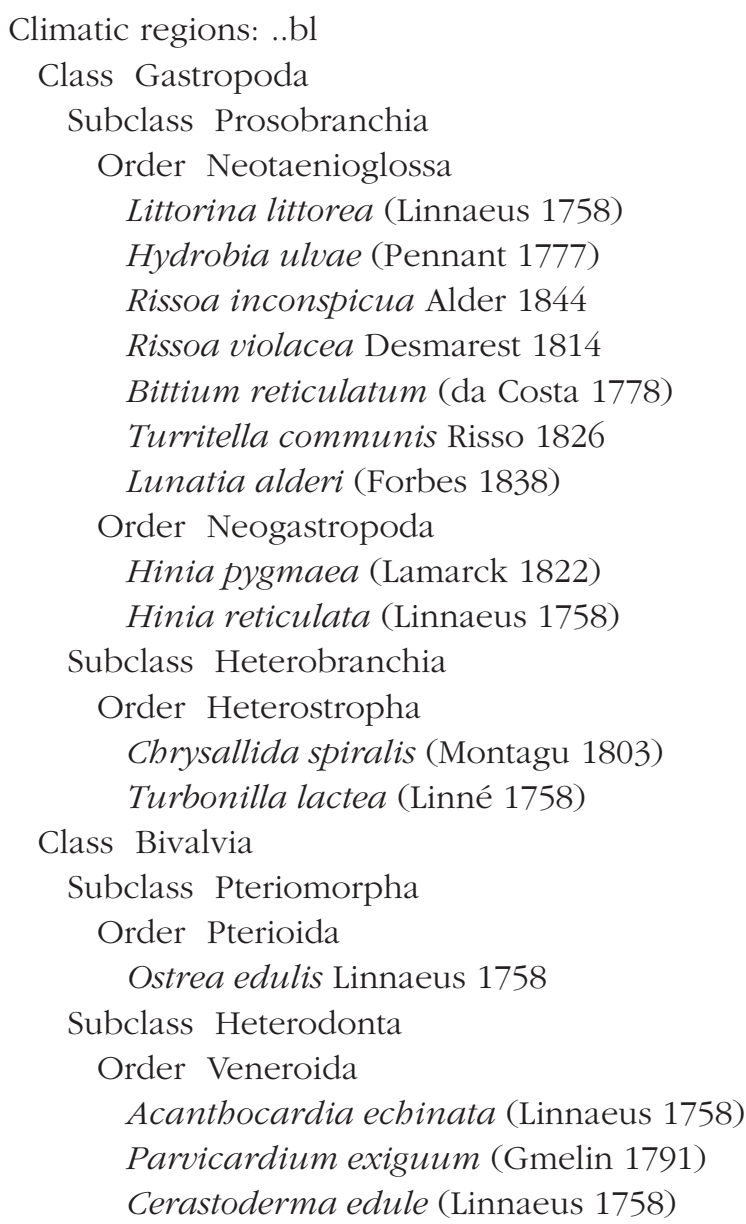

Climatic regions: ..bl

Class Gastropoda

bclass Prosobranchia

Order Neotaenioglossa Littorina littorea (Linnaeus 1758)

Hydrobia ulvae (Pennant 1777)

Rissoa inconspicua Alder 1844

Rissoa violacea Desmarest 1814

Bittium reticulatum (da Costa 1778)

rritella communis Risso 1826

Order Neogastropoda

Hinia pygmaea (Lamarck 1822)

bclass Heterobranchia

Order Heterostropha

Chrysallida spiralis (Montagu 1803 .

Turbonilla lactea (Linné 1758)

lass Bivalvi

bclass Pteriomorpha

rder Pterioida

donta

id

Parvicardium exiguum (Gmelin 1791) 
Laevicardium crassum (Gmelin 1791)

Spisula solida (Linnaeus 1758)

Spisula subtruncata (da Costa 1778)

Scrobicularia plana (da Costa 1778)

Abra prismatica (Montagu 1803)

Paphia aurea (Gmelin 1791)

Timoclea ovata (Pennant 1777)

Order Myoida

Corbula gibba (Olivi 1792)

Total for climatic regions ..bl: 23 (71.9\%)

\author{
Climatic regions: ...1 \\ Class Gastropoda \\ Subclass Opisthobranchia \\ Order Bullomorpha \\ Haminoea navicula (da Costa 1778) \\ Class Bivalvia \\ Subclass Pteriomorpha \\ Order Mytiloida \\ Mytilaster lineatus (Gmelin 1791) \\ Subclass Heterodonta \\ Order Veneroida \\ Lucinella divaricata (Linnaeus 1758) \\ Gastrana fragilis (Linnaeus 1758) \\ Paphia senescens (Cocconi 1873) \\ Total for climatic regions ...1: 5 (15.6\%)
}

The Eemian Kattegat: 32 (13.0\%)

From the region of the Kattegat sensu lato area, including the bordering landmasses with fjords, sounds and the northern part of the Lillebælt, Storebælt, and Øresund, three kinds of localities have been met with. As the information obtained from this area is based on a very different kind of material, the localities will be treated apart.

The first locality to be considered is Ejby Bro in northern Sjælland on the Isefjord. Here Erik Rasmussen (in Madsen 1968) described an in situ marine deposit.

Out of 15 mollusc species, two are Lusitanian, viz. Lucinella divaricata and Paphia aurea senescens, both of which are characteristic fossils of the Eemian.

Furthermore, out of ten Boreo-Lusitanian species, seven are not recorded from the recent Isefjord, viz. Rissoa violacea, Lunatia alderi, Hinia reticulata (the British form (Fretter \& Graham 1984, p. 495)), Ostrea edulis, Laevicardium crassum, Paphia aurea, and Spisula solida. Among these are also the less tolerant species regarding the region of lowest mean salinity inhabited, which is five species between $28 \%$ and 33\%
The present-day figure of salinity for the Isefjord is between 18 and 20\%. Although we have to do with a Saalien glacial topography, we may explain the higher salinity as a result of a higher tidal amplitude during the Eemian.

Only two species occurring in the Ejby Bro locality extend into the Subarctic: Buccinum undatum and Mytilus edulis, besides one - Hiatella arctica - having a wide range. All are present also in the recent Isefjord waters. This fauna points to a more oceanic environment than today and with a higher temperature; furthermore, the finds point to shallow-water or even beach deposits with some tidal influence (Rasmussen in Madsen 1968).

The second kind of locality includes redeposited sediments: either floes in the glacial deposits like the Stautrup locality at Aarhus or fluvioglacial deposits as at Høng in western Sjælland (Nordmann 1928, pp. 6465; Ødum 1933; Sorgenfrei 1945). Both of these localities carried some of the characteristic molluscs of the Eemian deposits. From Høng the following have been recorded: Lucinella divaricata and Paphia aurea senescens together with 11 species known from the Boreo-Lusitanian zone and Mytilus edulis known from the Subarctic to the Lusitanian regions. Only four species were also found at the Ejby Bro locality, and the 'new' ones (nine species) point to deeper water with such species as Acanthocardia echinata, Corbula gibba and Turritella communis.

The Stautrup material records new species to the Kattegat region such as Rissoa inconspicua, Mytilaster lineatus, Gastrana fragilis, Abra prismatica, Chrysallida spiralis, and Haminoea navicula, all except Mytilaster lineatus and Gastrana fragilis being Boreo-Lusitanian, while the two bivalves are limited to the Lusitanian and characteristic of the Eemian - together with Paphia aurea senescens, which is also present in the Stautrup floe, as discussed by Sorgenfrei (1945).

From the material hitherto discussed it appears that the Eemian sea deposits were known from the Kattegat region both in a shallow-water facies (Ejby Bro) and a deeper-water facies (Høng), the latter only from redeposited material. Therefore, it is of great importance from a palaeogeographical point of view that information now has been obtained from borings in the central part of the Kattegat, on the island of Anholt (Lykke-Andersen et al. 1993). Foraminifera from this well (Seidenkrantz 1993) revealed a marine Upper Saalian and Eemian sequence. The macrofossils from the well were kindly placed at my disposal. It appears that a temperate fauna with species such as Turritella 
communis, Aclis minor, Hiatella arctica, Nuculana minuta, and Scissurella crispata is resting on an Arctic deposit with Portlandia arctica. The information that we do have is that a Turritella facies within the Kattegat region in the Eemian found in an in situ position sustains the view of a continuation towards the north not only of the shallow-water deposits, but also of the deeper-water environment during the Eemian. Considering the bottom communities of the present-day Kattegat as revealed by Petersen (1913), Turritella communis is found in different associations at depths from 12-19 to $35 \mathrm{~m}$ on sand, fine sand and clay. The species from the Eemian of the Kattegat associated with Turritella communis in the Kattegat of today are Hiatella arctica, Nuculana minuta, Acanthocardia echinata, Corbula gibba, and Hinia pygmaea.

Considering the Eemian faunas demonstrated from the Kattegat region, it appears that here the lowest mean salinity inhabited by the species in question is within the present-day salinities reached for this area, at about 33\%o, although the salinities for the present fjords bordering the Kattegat have a lower salinity, as mentioned in the case of the Isefjord with the Ejby Bro locality.

\section{The North Sea}

\author{
Age: Eemian \\ Climatic regions: asb. \\ Class Bivalvia \\ Subclass Heterodonta \\ Order Veneroida \\ Tridonta elliptica (Brown 1827) \\ Total for climatic regions asb. : 1 (1.1\%) \\ Climatic regions: asbl \\ Class Gastropoda \\ Subclass Prosobranchia \\ Order Neotaenioglossa \\ Littorina saxatilis (Olivi 1792) \\ Class Bivalvia \\ Subclass Heterodonta \\ Order Veneroida \\ Thyasira flexuosa (Montagu 1803) \\ Tridonta montagui (Dillwyn 1817) \\ Order Myoida \\ Mya truncata Linnaeus 1758 \\ Hiatella arctica (Linnaeus 1758)
}

Total for climatic regions asbl: 5 (5.5\%)
Climatic regions: .sb.

Class Bivalvia

Subclass Heterodonta

Order Veneroida

Arctica islandica (Linnaeus 1767)

Total for climatic regions .sb. : 1 (1.1\%)

Climatic regions: .sbl

Class Gastropoda

Subclass Prosobranchia

Order Neotaenioglossa

Littorina obtusata (Linnaeus 1758)

Lacuna vincta (Montagu 1803)

Order Neogastropoda

Buccinum undatum Linnaeus 1758

Class Bivalvia

Subclass Pteriomorpha

Order Mytiloida

Mytilus edulis Linnaeus 1758

Modiolus modiolus (Linnaeus 1758)

Order Pterioida

Heteranomia squamula (Linnaeus 1758)

Subclass Heterodonta

Order Veneroida

Mysella bidentata (Montagu 1803)

Tellimya ferruginosa (Montagu 1803)

Parvicardium ovale (Sowerby 1840)

Macoma balthica (Linnaeus 1758)

Total for climatic regions .sbl: 10 (11.0\%)

Climatic regions: ..bl

Class Gastropoda

Subclass Prosobranchia

Order Archaeogastropoda Gibbula cineraria (Linnaeus 1758)

Order Neotaenioglossa

Littorina littorea (Linnaeus 1758)

Lacuna parva (Montagu 1803)

Hydrobia ulvae (Pennant 1777)

Onoba vitrea (Montagu 1803)

Rissoa albella Lovén 1846

Rissoa inconspicua Alder 1844

Rissoa membranacea (J. Adams 1800)

Rissoa parva (da Costa 1779)

Rissoa violacea Desmarest 1814

Caecum glabrum (Montagu 1803)

Bittium reticulatum (da Costa 1778)

Turritella communis Risso 1826

Aporrhais pespelicani (Linnaeus 1758)

Lunatia alderi (Forbes 1838)

Order Heterogastropoda 
Triphora adversa (Montagu 1803)

Cerithiopsis tubercularis (Montagu 1803)

Epitonium clathrus (Linnaeus 1758)

Order Neogastropoda

Hinia pygmaea (Lamarck 1822)

Hinia reticulata (Linnaeus 1758)

Cytharella coarctata (Forbes 1840)

Subclass Heterobranchia

Order Heterostropha

Brachystomia eulimoides Hanley 1844

Odostomia scalaris MacGillivray 1843

Chrysallida obtusa (Brown 1827)

Chrysallida spiralis (Montagu 1803)

Ebala nitidissima (Montagu 1803)

Odostomia albella Lovén 1846

Turbonilla crenata (Brown 1827)

Turbonilla lactea (Linné 1758)

Subclass Opisthobranchia

Order Bullomorpha

Acteon tornatilis (Linnaeus 1758)

Philine aperta (Linnaeus 1767)

Order Anaspidea

Retusa truncatula (Bruguière 1792)

Akera bullata Müller 1776

Class Bivalvia

Subclass Palaeotaxodonta

Order Nuculoida

Nucula nitidosa Winckworth 1930

Nucula sulcata (Bronn 1831)

Subclass Pteriomorpha

Order Mytiloida

Modiolula phaseolina (Philippi 1844)

Modiolaria tumida (Hanley 1843)

Order Pterioida

Aequipecten opercularis (Linnaeus 1758)

Chlamys varia (Linnaeus 1758)

Ostrea edulis Linnaeus 1758

Subclass Heterodonta

Order Veneroida

Lepton nitidum (Turton 1822)

Acanthocardia echinata (Linnaeus 1758)

Parvicardium exiguum (Gmelin 1791)

Parvicardium scabrum (Philippi 1844)

Cerastoderma edule (Linnaeus 1758)

Spisula subtruncata (da Costa 1778)

Ensis ensis (Linnaeus 1758)

Phaxas pellucidus (Pennant 1777)

Angulus tenuis (da Costa 1778)

Tellina donacina Linnaeus 1758

Fabulina fabula (Gmelin 1791)

Donax vittatus (da Costa 1778)
Scrobicularia plana (da Costa 1778)

Abra alba (Wood 1802)

Abra prismatica (Montagu 1803)

Chamelea striatula (da Costa 1778)

Tapes decussatus (Linnaeus 1758)

Timoclea ovata (Pennant 1777)

Venerupis pullastra (Montagu 1803)

Dosinia lincta (Montagu 1803)

Mysia undata (Pennant 1777)

Order Myoida

Corbula gibba (Olivi 1792)

Saxicavella jeffreysi Winckworth 1930

Barnea candida (Linnaeus 1758)

Subclass Anomalodesmata

Order Pholadomyoida

Thracia phaseolina (Lamarck 1818)

Thracia villosiuscula (MacGillivray 1827)

Total for climatic regions ..bl: 66 (72.5\%)

Climatic regions: ...1

Class Gastropoda

Subclass Opisthobranchia

Order Bullomorpha

Haminoea navicula (da Costa 1778)

Class Bivalvia

Subclass Pteriomorpha

Order Mytiloida

Mytilaster lineatus (Gmelin 1791)

Subclass Heterodonta

Order Veneroida

Lucinella divaricata (Linnaeus 1758)

Plagiocardium papillosum Poli 1795

Gastrana fragilis (Linnaeus 1758)

Abra segmentum (Récluz 1843)

Paphia senescens (Cocconi 1873)

Gouldia minima (Montagu 1803)

Total for climatic regions ...1: 8 (8.8\%)

The Eemian North Sea: 91 (36.8\%)

Regarding the Eemian deposits of south-western Jylland several localities are included: Tønder and surroundings, Forballum, Farup, Ydre Bjergum, Mandø Hølade (many places) and Inder Bjergum. Furthermore, also molluscs of Eemian age are recorded from the map sheet Blaavands Huk (Fig. 1). In all, 91 molluscan species have been recorded, 53 bivalves and 38 gastropods. This high number of species comprises 32 species new to the Eemian compared to the Brelt Sea deposits. 
Considering the new elements from the climatic point of view, two are Lusitanian species, Plagiocardium papillosum and Mytilaster lineatus, which are regarded as part of the characteristic species of the Eemian fauna (Nordmann 1928).

By far the largest group of new species in the North Sea deposits are the Boreo-Lusitanian. Only one - Tridonta elliptica - does not extend into the Lusitanian region. This is close to the situation found in the Bælt Sea region, where only two species; Arctica islandica and Zirfaea crispata, do not reach the Lusitanian region.

Arctica islandica - so common in the Bæelt Sea deposits - has been recorded only in a single find of a juvenile specimen at Mandø Hølade in south-western Jylland. The other species, Zirfaea crispata, has not been demonstrated at all in the Danish North Sea Eemian deposits.

The Boreo-Lusitanian species Mactra stultorum has a high salinity requirement, occurring in the Bælt Sea region but not in the Danish North Sea region during the Eemian.

This has been used as an argument against uniting in time the deposits found on the western and eastern sides of southern Jylland. "On a voulu y voir une preuve que ces deux bassins de mer n'out en réalité rien eu à faire l'un avec l'autre, en sorte qu'ils pourraient très bien être d'àges fort différents" (Nordmann 1928, p. 63).

When the 15 mollusc species of the Eemian Bælt Sea fauna mentioned earlier with a salinity requirement between 30-33\% are remembered, the former focus on Mactra stultorum is of less significance.

While Nordmann states that the fauna on both sides of the Jylland peninsula can be regarded as one, he is right from the point of view of climatic conditions, as demonstrated above. However, he is also arguing for a connection between the North Sea and the Brlt Sea (Nordmann 1928, p. 63): "Les passes entre les parties orientale et occidentale de la mer eemienne, ce qui, autrement parlant, signifie les vallées et les plaines entre les collines insulaires qui sont aujourd'hui occupées par les plaines de landes du Slesvig et du Holstein, sont sans doute très etroites". However, it is the author's opinion that the difference between the southern Danish localities to the east (the Bæelt Sea) and to the west (the North Sea) can be regarded as differences in facies that are also found in present-day Danish waters. Here the occurrences of Donax vittatus in the Eemian North Sea deposits, but not in the Bælt Sea deposits, should be considered. Donax vittatus is a characteristic species of the high-energy coastal envi- ronment, where it is found all along the present-day west coast, but not in the inner Danish waters from the northernmost part of the east coast of Jylland.

However, many of the other molluscs might have made their way to the Brelt Sea and the Baltic region if there has been only the slightest passage over southern Jylland.

In the case of a passage, the situation can be looked upon as a parallel to the present-day marine colonisation of the Limfjord after the breaking through by the North Sea at the Spit at Agger in 1825. At the end of the 19th century a rich marine fauna could be recorded in the Limfjord (Collin 1884; Petersen 1888).

The question of connection between the North Sea and the Bxlt Sea over the southern part of the peninsula of Jylland can be considered, based on the mollusc assemblages. It appears that the difference in faunal composition during the Eemian in both seas was very similar to the difference in faunas during the Holocene, although with Lusitanian shallow-water species occurring during the Eemian. Therefore it must be concluded that the land-sea configuration must be very much the same during the two periods so Jylland was also a peninsula during the Eemian.

\section{Vendsyssel}

\author{
Age: Eemian \\ Climatic regions: asb. \\ Class Gastropoda \\ Subclass Prosobranchia \\ Order Neogastropoda \\ Oenopota incisula (Verrill 1882) \\ Oenopota violacea (Mighels \& Adams 1842) \\ Bela exarata G.O. Sars 1818 \\ Class Bivalvia \\ Subclass Palaeotaxodonta \\ Order Nuculoida \\ Nuculana pernula (Müller 1776) \\ Yoldiella lenticula (Möller 1842) \\ Subclass Pteriomorpha \\ Order Mytiloida \\ Musculus niger (Gray 1824) \\ Subclass Heterodonta \\ Order Veneroida \\ Clinocardium ciliatum (Fabricius 1780) \\ Serripes groenlandicus (Bruguière 1798) \\ Macoma calcarea (Gmelin 1791)
}

Total for climatic regions asb. : 9 (16.4\%) 


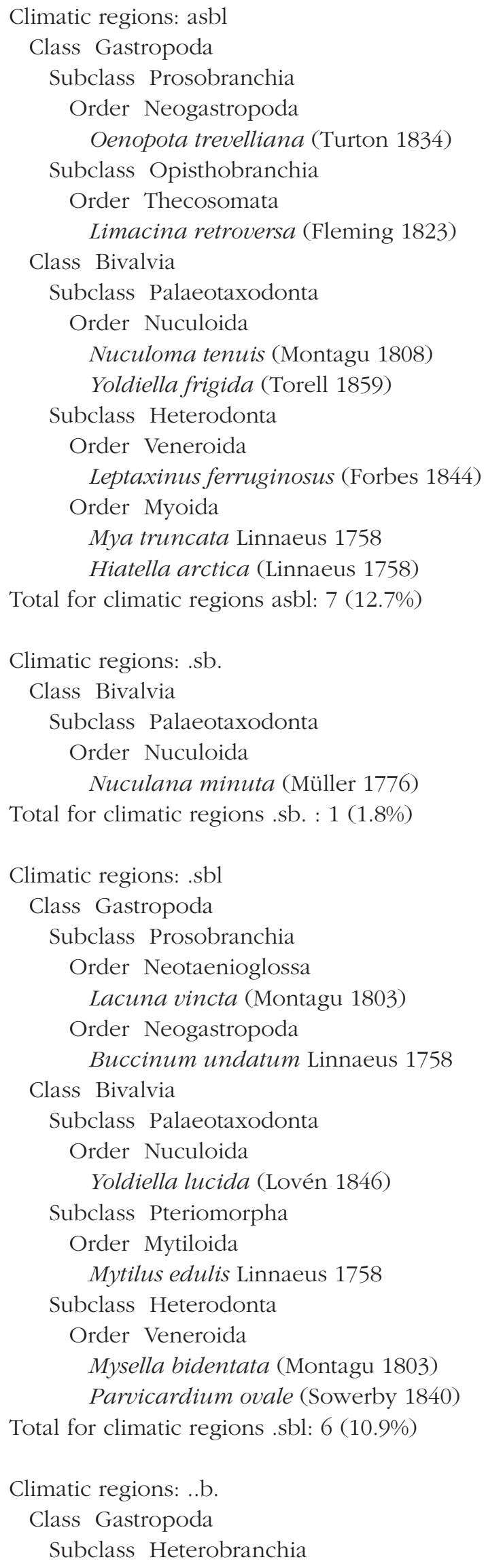

Order Heterostropha

Chrysallida eximia (Jeffreys 1849)

Total for climatic regions ..b. : 1 (1.8\%)

Climatic regions: ..bl

Class Gastropoda

Subclass Prosobranchia

Order Neotaenioglossa

Alvania abyssicola (Forbes 1850)

Rissoa parva (da Costa 1779)

Bittium reticulatum (da Costa 1778)

Turritella communis Risso 1826

Aporrhais pespelicani (Linnaeus 1758)

Lunatia alderi (Forbes 1838)

Order Heterogastropoda

Vitreolina philippii (Rayneval \& Ponzi 1854)

Order Neogastropoda

Hinia incrassata (Ström 1768)

Hinia reticulata (Linnaeus 1758)

Mangelia brachystoma (Philippi 1844)

Raphitoma linearis (Montagu 1803)

Subclass Heterobranchia

Order Heterostropha

Eulimella scillae (Scacchi 1835)

Ondina divisa (J. Adams 1797)

Odostomia turrita Hanley 1844

Subclass Opisthobranchia

Order Bullomorpha

Acteon tornatilis (Linnaeus 1758)

Order Anaspidea

Retusa umbilicata (Montagu 1803)

Class Bivalvia

Subclass Palaeotaxodonta

Order Nuculoida

Nucula nucleus (Linnaeus 1767)

Nucula sulcata (Bronn 1831)

Yoldiella philippiana (Nyst 1845)

Subclass Pteriomorpha

Order Pterioida

Pseudamussium septemradiatum

(Müller 1776)

Similipecten similis (Laskey 1811)

Subclass Heterodonta

Order Veneroida

Acanthocardia echinata (Linnaeus 1758)

Parvicardium minimum (Philippi 1836)

Ensis ensis (Linnaeus 1758)

Phaxas pellucidus (Pennant 1777)

Abra alba (Wood 1802)

Abra nitida (Müller 1776)

Abra prismatica (Montagu 1803) 


\author{
Kelliella miliaris (Philippi 1844) \\ Chamelea striatula (da Costa 1778) \\ Order Myoida \\ Corbula gibba (Olivi 1792)
}

Total for climatic regions ..bl: 31 (56.4\%)

The Eemian Vendsyssel: 55 (22.3\%)

In Vendsyssel the mollusc faunas in the Skærumhede sequence have been studied by Nordmann (Jessen et al. 1910) and Petersen (Bahnson et al. 1974). The conclusion reached in the latter study on molluscs points out that the difference between the Boreo-Lusitanian community - the Turritella terebra zone - in the boring and the typical Eemian community in southern Denmark is a difference in facies.

This statement will be discussed now on the basis of all the mollusc found and listed according to their climatic regions.

Among the 55 species of molluscs recorded from the Eemian in the Vendsyssel region, no Lusitanian species occur, but Boreo-Lusitanian species count for more than half of the assemblages (31 species, $56.4 \%$ ). Of these, 25 are mentioned in the list for region of lowest mean salinity inhabited built on information from the Danish waters in the transition area between the North Sea (at Esbjerg) and the Baltic (Gulf of Bothnia) (Sorgenfrei 1958). Nearly $4 / 5$ of this number have their region of lowest mean salinity between $24 \%$ and $34 \%$, which is the minimum, and mean salinities at the passage belt between the North Sea - Skagerrak and E and NW Kattegat. This situation for an Eemian assemblage indicates a high degree of similarity with the present-day environment in this area.

Within the Boreo-Lusitanian group of molluscs there is a clear dominance of species belonging to the deeperwater environment at around the $100 \mathrm{~m}$ depth. However, there are some few species which belong at a depth of less than 20-30 m. Such species are Rissoa parva, Hinia reticulata and Retusa umbilicata, which within their depth range live in great abundance, which is not the case in the Skærumhede sequences. Therefore they can be regarded as allochthonous or as stray finds outside their environment. Nordmann (in Jessen et al. 1910) mentioned that Rissoa parva and Hinia reticulata were redeposited. He also mentioned Bittium reticulatum, which according to the literature has some records from the deeper water (out to $250 \mathrm{~m}$ deep).

Taking the whole group of Boreo-Lusitanian species, there are many which occur in the tidal and shal- low-water environments but have a wide range of depth. Rather few are those which are mainly connected with the deeper water - here depths of more than $10 \mathrm{~m}$ - viz.: Turritella communis, Lunatia alderi, Mangelia brachystoma, Raphitoma linearis, Eulimella scillae, Nucula sulcata, Pseudamussium septemradiatum and Kelliella miliaris. The last one strengthens the depth indications to be more than $100 \mathrm{~m}$, since the species is recently known only from the deeper part of the Skagerrak.

Chrysallida eximia, which is found at depths from 20-1000 $\mathrm{m}$ is here regarded as a Boreal species, although it extends into the northernmost part of the Lusitanian zone, but there in deeper water.

Among the species known from the Subarctic to the Lusitanian regions, the finds of Mytilus edulis (Jessen et al. 1910; Bahnson et al. 1974) can be regarded from the same point of view as mentioned in connection with Rissoa parva and Hinia reticulata. The few finds of Mytilus specimens clearly indicate that this normally gregariously living species is found outside its living zone and can be regarded also as stray finds.

The other finds of species occurring in the Subarctic to the Lusitanian zone do not oppose the view of a deeper-water environment.

Taking the species together which do not occur in the Lusitanian zone but extend into the Arctic or Subarctic (Nuculana minuta), there are two species Clinocardium ciliatum and Serripes groenlandicus, which do pose a problem regarding their climatic indications within the Skærumhede sequence. These two species are found only in the High Boreal zone (Norway north of Lofoten). Nordmann (Jessen et al. 1910, pp. 127128) mentioned the occurrences of these species off Iceland together with other species with which they occur in the Skærumhede sequence.

This picture has been to some degree changed by the publication of parts of the Zoology of Iceland, so it appears that Turritella communis is no longer regarded as being part of the Icelandic fauna, while Eulimella scillae (only empty shells) might be added. Lunatia alderi and Raphitoma linearis mentioned by Nordmann are confirmed (Thorson 1941), and so is Acteon tornatilis (Lemche 1938), in the new literature. However, in this way we still face the question of the climatic conditions indicated by the molluscan assemblage.

However, as seen from the latest Skærumhede boring (Bahnson et al. 1974, fig. 7), there is a clear transition zone between the Turritella communis zone and the establishment of the Turritella erosa zone. In this zone, the so-called Abra nitida zone, we still find the 
mixing of species with different climatic affinities, just as we do not have a sharp border zone to tell where we actually leave the Eemian and pass into the Weichselian. But we do have a well-defined bottom community for what we must call the Eemian from the Vendsyssel region, and that is the Turritella communis community. This community we find in deeper water, also in the recent Danish waters.

Oenopota incisula is one of the species also occurring in the transition zone between the two Turritella communities, the Boreal-Lusitanian with T. communis, and the Arctic with T. erosa. Oenopota incisula has been found in both borings (Jessen et al. 1910; Bahnson et al. 1974, fig. 7), but the species has still not been recorded from the European coast of the North Atlantic in recent time. In this way Oenopota incisula becomes one of the few species extinct in our part of the world since the Early/Middle Weichselian.

Finally the six species with a wide range within the climatic regions are all found in deeper water. However, here Yoldiella frigida occurs in deeper water in the southern part of its range. Limacina retroversa is a pelagic species and has been recorded in the present day to penetrate into the Kattegat - Bælt Sea regions.

\section{Skagen}

\author{
Age: Eemian \\ Climatic regions: asb. \\ Class Bivalvia \\ Subclass Palaeotaxodonta \\ Order Nuculoida \\ Nuculana pernula (Müller 1776) \\ Total for climatic regions asb. : 1 (7.1\%)
Climatic regions: asbl
Class Gastropoda
Subclass Opisthobranchia
Order Thecosomata \\ Limacina retroversa (Fleming 1823) \\ Class Scaphopoda \\ Siphonodentalium lobatum (Sowerby 1860) \\ Class Bivalvia \\ Subclass Palaeotaxodonta \\ Order Nuculoida \\ Yoldiella frigida (Torell 1859) \\ Subclass Heterodonta \\ Order Myoida \\ Hiatella arctica (Linnaeus 1758) \\ Total for climatic regions asbl: 4 (28.6\%)
}

\author{
Climatic regions: .sbl \\ Class Scaphopoda \\ Antalis entalis (Linnaeus 1758) \\ Class Bivalvia \\ Subclass Pteriomorpha \\ Order Pterioida \\ Delectopecten vitreus (Gmelin 1791)
}

Total for climatic regions .sbl: 2 (14.3\%)

\author{
Climatic regions: ..bl \\ Class Gastropoda \\ Subclass Prosobranchia \\ Order Neotaenioglossa \\ Lunatia alderi (Forbes 1838) \\ Subclass Opisthobranchia \\ Order Bullomorpha \\ Philine catena (Montagu 1803) \\ Class Scaphopoda \\ Cadulus subfusiforme (M. Sars 1865) \\ Entalina tetragona (Brocchi 1814) \\ Class Bivalvia \\ Subclass Heterodonta \\ Order Veneroida \\ Kelliella miliaris (Philippi 1844) \\ Subclass Anomalodesmata \\ Order Pholadomyoida \\ Cochlodesma praetenue (Pulteney 1799) \\ Total for climatic regions ..bl: 6 (42.9\%)

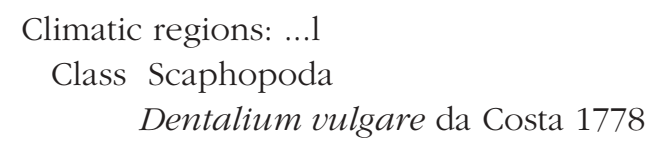

Climatic regions: ...1

Class Scaphopoda

Dentalium vulgare da Costa 1778

Total for climatic regions ...1: 1 (7.1\%)

The Eemian Skagen: 14 (5.7\%)

In the Eemian part of the Skagen Well, one species, Dentalium vulgare, mainly occurs within the Lusitanian region and is not recorded from recent Danish waters, although it is found in the southern part of the North Sea.

Among the six Boreo-Lusitanian mollusc species, Cochlodesma praetenue is rare in Danish waters, while all the others as far as the information on habitats goes are connected with the deeper-water environment. This is also true for the species including the Subarctic region, viz.: Antalis entalis and Delectopecten vitreus, where the latter in general has a depth range from 30$600 \mathrm{~m}$, but in Skagerrak is found between 400 and $600 \mathrm{~m}$. Also Antalis entalis has a wide range of depth, 
but within Danish water it is recorded only from 20-400 m.

The four species: Siphonodentalium lobatum, Limacina retroversa, Yoldiella frigida and Hiatella arctica with a wide geographical distribution from the Arctic to the Lusitanian also have a wide range of depth.

Also Nuculana permula, here listed from the Arctic to the Boreal, could be considered to have a wide range like the other species mentioned above, however, in SW Europe it is found only at depths greater than $400 \mathrm{~m}$. In recent Danish waters it occurs at depths from 20 to $200 \mathrm{~m}$. Seen together with the other species in this region during the Eemian with a more southern affinity, Nuculana pernula shows accordance, considering that the species in the Arctic is mostly littoral.

Comparing the assemblages from the faunal elements from Skærumhede, it appears that the Skagen Well depicts a deeper-water community without any influence from more shallow-water facies.

The occurrence of three of the four Scaphopoda Cadulus subfusiforme, Entalina tetragona and Antalis entalis speaks in favour of an environment which is likely to be found in the deeper Skagerrak, such as the Amphilepis norvegica/Pecten vitreus community with Entalinatetragona and of which one of the other molluscs, Delectopecten vitreus, is considered a characteristic species.

The demonstrated Eemian assemblages in most of the Danish regions show differences in climatic affinities - more Lusitanian in the southern part - which, however, can be explained through an analysis of the faunas in their relation to depth - shallow-water Lusitanian species in the south - and in some parts in relation to the community.

The community concept which was developed for the recent Danish waters does not find its equivalent in the Eemian Bælt Sea and Baltic regions, only partly in the Kattegat region, but has a good correlation with the occurrences of the faunal assemblages in the regions to the north in Jylland - the Vendsyssel and Skagen regions - only in these two regions does the succession of strata allow us to follow the development into the Weichselian cooler/Arctic molluscan fauna, although we find some deposits from the Kattegat region (Holmstrup and Holbæk sites) which can be correlated to the Early/Middle Weichselian in the Vendsyssel and Skagen region.

\section{Early/Middle Weichselian species sorted after climatic affinities}

\section{The Kattegat}

\author{
Age: Early/Middle Weichselian \\ Climatic regions: a... \\ Class Bivalvia \\ Subclass Palaeotaxodonta \\ Order Nuculoida \\ Portlandia arctica (Gray 1824) \\ Total for climatic regions a... : 1 (14.3\%) \\ Climatic regions: as.. \\ Class Gastropoda \\ Subclass Opisthobranchia \\ Order Bullomorpha \\ Cylichna occulta (Mighels 1841) \\ Total for climatic regions as.. : 1 (14.3\%) \\ Climatic regions: asb. \\ Class Bivalvia \\ Subclass Palaeotaxodonta \\ Order Nuculoida \\ Nuculana pernula (Müller 1776) \\ Subclass Heterodonta \\ Order Veneroida \\ Macoma calcarea (Gmelin 1791)
}

Total for climatic regions asb. : 2 (28.6\%)

Climatic regions: asbl

Class Bivalvia

Subclass Palaeotaxodonta

Order Nuculoida

Nuculoma tenuis (Montagu 1808)

Subclass Heterodonta

Order Myoida

Mya truncata Linnaeus 1758

Hiatella arctica (Linnaeus 1758)

Total for climatic regions asbl: 3 (42.9\%)

The Early/Middle Weichselian Kattegat: 7 (2.8\%)

In the Kattegat region, two localities (Holbæk and Holmstrup, Fig. 1) have mollusc faunas of Early/Middle Weichselian age, which could be correlated to the Older Yoldia Clay deposits found in the Vendsyssel and Skagen regions.

Nordmann (Ødum 1933) described the mollusc fauna in the borings at Holbæk to represent part of the Port- 
landia arctica zone in the Skærumhede sequence (Jessen et al. 1910). Later, Petersen \& Buch (1974) referred the outcrops at Holmstrup with marine clay, characterised by Macoma calcarea, to the Weichselian part of the sequence close to the Macoma calcarea zone (Bahnson et al. 1974) in the new well at Skærumhede in the Vendsyssel region.

The later correlation was mainly based on the foraminiferal studies (Buch in Petersen \& Buch 1974). Also aminostratigraphic investigations have to some extent sustained this correlation (Miller \& Mangerud 1985, p. 261). The mollusc faunas from these two localities point to an Arctic environment as seen from the climatic indications, in that all seven species are found in the Arctic and only three of them with a wide range: Hiatella arctica, Mya truncata and Nuculoma tenuis.

Taken into account that these deposits show an Arctic affinity, the interpretation of depth ranges of the species found point to the more shallow-water environment. This is also true for species such as Nuculoma tenuis, which is recorded from offshore down to 300 $\mathrm{m}$ deep, but in the Arctic is more littoral.

Macoma calcarea is found intertidal to several hundred metres, but only in deeper water in the southern part of the range for this species. In the Arctic it is the characterising mollusc in shallow water: the Arctic Macoma calcarea community. Furthermore, Nuculana pernula, as mentioned earlier, is littoral in the Arctic.

The conclusion to draw from these finds in the Kattegat region is that we have a part - the more shallow water - of the Arctic zones recorded from the Vendsyssel region represented within the Kattegat region southern part.

\section{Vendsyssel}

Age: Early/Middle Weichselian

Climatic regions: a...
Class Bivalvia
Subclass Palaeotaxodonta
Order Nuculoida
Portlandia arctica (Gray 1824)
Total for climatic regions a... : 1 (2.8\%)
Climatic regions: as..
Class Gastropoda
Subclass Prosobranchia
Order Neotaenioglossa
Alvania cruenta Odhner 1915
Turritella erosa Couthouy 1838

Subclass Opisthobranchia

Order Bullomorpha

Cylichna occulta (Mighels 1841)

Class Bivalvia

Subclass Pteriomorpha

Order Arcoida

Batbyarca glacialis (Gray 1824)

Subclass Anomalodesmata

Order Pholadomyoida

Pandora glacialis Leach 1819

Lyonsia arenosa (Möller 1842)

Total for climatic regions as.. : 6 (16.7\%)

Climatic regions: asb.

Class Gastropoda

Subclass Prosobranchia

Order Neotaenioglossa

Alvania scrobiculata (Möller 1842)

Alvania jan mayeni (Friele 1886)

Lunatia pallida (Broderip \& Sowerby 1829)

Order Neogastropoda

Oenopota incisula (Verrill 1882)

Admete viridula (Fabricius 1780)

Subclass Opisthobranchia

Order Anaspidea

Retusa obtusa (Montagu 1803)

Class Bivalvia

Subclass Palaeotaxodonta

Order Nuculoida

Nuculana pernula (Müller 1776)

Yoldia byperborea Lovén 1859

Yoldiella lenticula (Möller 1842)

Subclass Pteriomorpha

Order Mytiloida

Musculus laevigatus (Gray 1824)

Musculus niger (Gray 1824)

Crenella decussata (Montagu 1803)

Order Pterioida

Palliolum greenlandicum (Sowerby 1842)

Subclass Heterodonta

Order Veneroida

Axinopsida orbiculata (G.O. Sars 1878)

Tridonta borealis Schumacher 1817

Tridonta elliptica (Brown 1827)

Clinocardium ciliatum (Fabricius 1780)

Serripes groenlandicus (Bruguière 1798)

Macoma calcarea (Gmelin 1791)

Total for climatic regions asb. : 19 (52.8\%) 


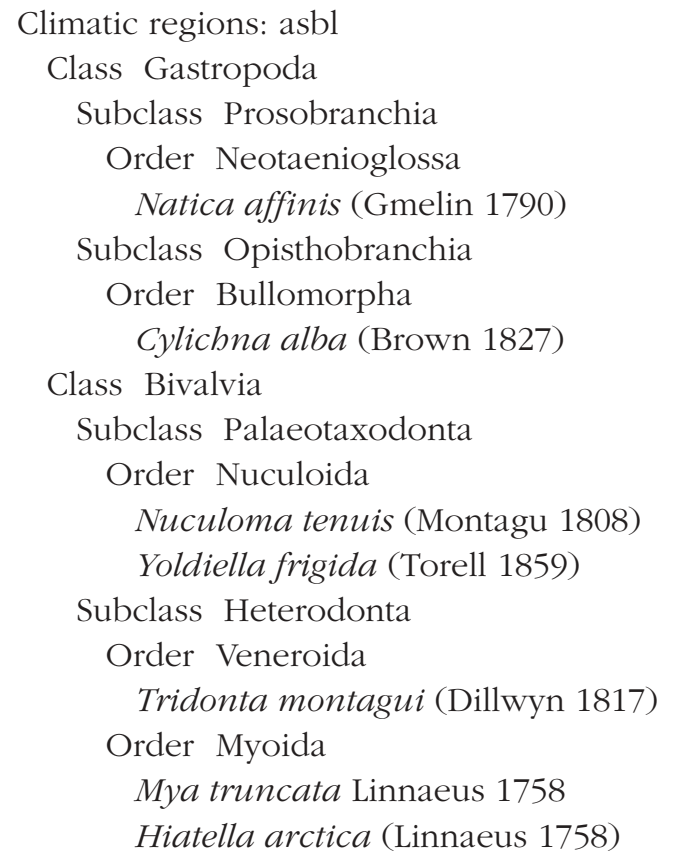

Total for climatic regions asbl: 7 (19.4\%)

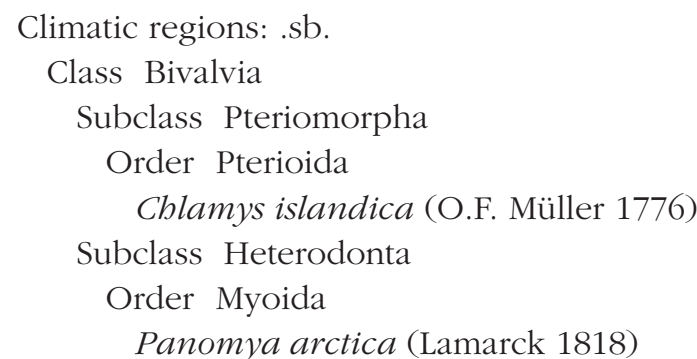

Total for climatic regions .sb. : 2 (5.6\%)

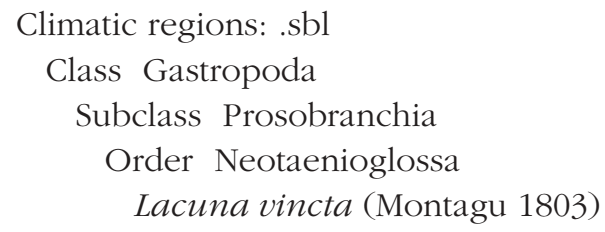

Total for climatic regions .sbl: 1 (2.8\%)

The Early/Middle Weichselian Vendsyssel: 36 (14.6\%)

The mollusc fauna from the Vendsyssel region during the Early/Middle Weichselian amounts to 36 species, which would have been even more if not reduced to this number by excluding species regarded as redeposited by V. Nordmann (Jessen et al. 1910). Almost all the recorded species have been found in the Skærumhede borings I and II (Jessen et al. 1910; Bahnson et al. 1974 respectively), except Lunatia pallida, Bathyarca glacialis, Musculus laevigatus and Tridonta borealis, which have been recorded from the Older Yoldia Clay elsewhere in Vendsyssel.
Taken together, the two borings form a most excellent base for evaluating the mollusc faunal development in the Early/Middle Weichselian represented by the Arctic sea deposits characterised by Portlandia arctica. However, on the basis of the material from Skærumhede (Bahnson et al. 1974), the Portlandia arctica zone is divided into three parts each characterised by other macrofossils from the older to the younger beds: the Turritella erosa, Balanus crenata and Macoma calcarea zones. By doing so, it is emphasised that the development in the Arctic part of the marine sequence goes from a deeper-water facies into a shallow-water facies, where in the latter the Macoma calcarea species is the dominant bivalve, as it is in the present-day Arctic Macoma community of East Greenland (Thorson 1933).

From a climatic point of view, nearly all the molluscan species can be found in the High Arctic, except Lacuna vincta, Panomya arctica and Chlamys islandica, which are recorded only from the Subarctic. However, two of them occur in the Turritella erosa zone, which at the same time has the most abundant representation of the other species with northern/Arctic affinities, including the purely Arctic species Portlandia arctica. Therefore, no rise in temperature can be suggested on the basis of the molluscan record, only changes in facies through time.

Together with the dominant molluscan species Portlandia arctica and Macoma calcarea in the upper part of the Arctic sequence - the Balanus crenata and the Macoma calcarea zones (as seen on fig. 7 in Bahnson et al. 1974) - the following mollusc species have been recorded only from these zones: Natica affinis, Musculus niger, Palliolum greenlandicum, and Axinopsida orbiculata. All of them can be found in shallow water in the Arctic. Considering the change of facies from deeper water to shallow water and the lack of climatic changes as seen in the molluscan fauna the question arises of what length of time this development covers.

This question has been answered by the two AMS dates of the topmost part of the marine Skærumhede sequence $33 \mathrm{~m}$ b.s., which give the age of around 32000 ${ }^{14} \mathrm{C}$ years before present (AAR-1410: $32400 \pm 520$ and AAR-1411: $32050 \pm 420$ - both reservoir corrected ${ }^{14} \mathrm{C}$ age (B.P.)). This shows that the marine Arctic deposits in this part of the Danish area represent nearly the whole part of the Early and Middle Weichselian, because there is an unbroken marine sequence below the level for these AMS dates and back into the Eemian.

On the basis of the correlation of the Holmstrup sequence of clay with Macoma calcarea, there are rea- 
sons to think that also the southern part of the Kattegat region was part of the Older Yoldia Clay Sea far into the Weichselian, even though two AMS datings from the Holmstrup site were infinite (AAR-1408: > 38 $000{ }^{14} \mathrm{C}$ age (B.P.) and AAR-1409: $>42000{ }^{14} \mathrm{C}$ age (B.P.)).

\section{Skagen}

\author{
Age: Early/Middle Weichselian \\ Climatic regions: a... \\ Class Bivalvia \\ Subclass Palaeotaxodonta \\ Order Nuculoida \\ Portlandia arctica (Gray 1824) \\ Total for climatic regions a... : 1 (25.0\%) \\ Climatic regions: asb. \\ Class Bivalvia \\ Subclass Palaeotaxodonta \\ Order Nuculoida \\ Nuculana pernula (Müller 1776) \\ Yoldia hyperborea Lovén 1859 \\ Subclass Pteriomorpha \\ Order Pterioida \\ Palliolum greenlandicum (Sowerby 1842) \\ Total for climatic regions asb. : 3 (75.0\%)
}

The Early/Middle Weichselian Skagen: 4 (1.6\%)

In the Skagen region, where all the information coming from the well has been described in more detail earlier, the macrofossil fauna can be presented on the basis of quantitative analyses and sedimentological data (Appendix 3). Therefore, the material can be seen on the background of a certain bottom community. Such a relation was already seen realised in the discussion of the Eemian strata in the Skagen region, which pointed out that these strata could be correlated with an environment of the deeper part of the present Skagerrak. However, the change found in the Arctic section of the Skagen Well on the basis of the mollusc record occurs rather abruptly, turning the scenario into an Arctic environment with ice-rafted minerogene material.

Such a palaeoenvironment is far from the communities demonstrated in recent Danish waters, but is well known from East Greenland. Regarding the finds from the Arctic part of the Skagen sequence following the temperated Eemian strata, it appears that there are no finds of bias from nearshore or indications of other climatic conditions than from the Arctic. The four molluscan species found are recorded either only in the High-Arctic, viz. Portlandia arctica, or in the three zones from the Arctic to the Boreal, viz. Nuculana pernula, Yoldia hyperborea, and Palliolum greenlandicum.

This is a different situation than found in the Vendsyssel region, where the two Skærumhede Wells revealed a clear transition zone - the so-called Abra nitida zone - and within the Arctic part, with occurrence of molluscs which have been regarded as redeposited (Nordmann in Jessen et al. 1910), such as: Mytilus edulis, Pseudamussium septemradiatum, Zirfaea crispata, and Bittium reticulatum.

It has been argued in the present paper in connection with the Holocene strata from Skagen that, due to the expired isostatic uplift since the Weichselian glaciation, the actual depth below present sea level of the Holocene beds can be regarded as representing the palaeodepth - taken into account the eustatic movements through time. If this is true, the older strata the Eemian and Early Weichselian - may also be in a position below present sea level, which could reflect their palaeodepth, here also taking into consideration the older eustatic situation and the question of consolidation. Neotectonic movements might be the black horse together with the higher level of the sea during the Eemian, max. 7-8 $\mathrm{m}$ above the present level. This shows that the transition zone - the Abra nitida zone - in the Skærumhede II Well is found at a present depth below sea level of between 78 and $88 \mathrm{~m}$ (Bahnson et al. 1974, fig. 7), while the sharp boundary between the temperate and the Arctic zone in the Skagen Well is at a depth of $180 \mathrm{~m}$ b.s.

The sea level must have been the same for the two stations at this time, so the difference in depth must be around $100 \mathrm{~m}$. Therefore the difference in development of the mollusc fauna within the two sequences depends on depths. This might also explain the occurrences of redeposited molluscs from shallow water in the Skærumhede sequence and not in the Skagen sequence by a closer coastal environment.

The further development of the marine Arctic in the Skagen region has been truncated by the glaciation within the area. However, as demonstrated earlier, the overlying glacigene deposits have indeed accumulated the 'missing' younger marine strata up to an age of around 32000 before present, as shown by dating of the marine gases. 


\section{Late Weichselian species sorted after climatic affinities}

\section{Vendsyssel}

Age: Late Weichselian

Climatic regions: a...

Class Bivalvia

Subclass Palaeotaxodonta

Order Nuculoida

Portlandia arctica (Gray 1824)

Subclass Heterodonta

Order Veneroida

Macoma torelli Jensen 1904

Total for climatic regions a... : 2 (5.7\%)

Climatic regions: as..

Class Gastropoda

Subclass Opisthobranchia

Order Bullomorpha Cylichna occulta (Mighels 1841)

Class Bivalvia

Subclass Heterodonta

Order Veneroida

Macoma loveni Jensen 1904

Subclass Anomalodesmata

Order Pholadomyoida

Pandora glacialis Leach 1819

Lyonsia arenosa (Möller 1842)

Total for climatic regions as.. : 4 (11.4\%)

Climatic regions: asb.

Class Gastropoda

Subclass Prosobranchia

Order Neotaenioglossa

Lunatia pallida (Broderip \& Sowerby 1829)

Order Neogastropoda

Boreotrophon clathratus (Linnaeus 1767)

Buccinum cyaneum Bruguière 1792

Neptunea despecta (Linnaeus 1758)

Oenopota turricola (Montagu 1803)

Subclass Opisthobranchia

Order Anaspidea

Retusa obtusa (Montagu 1803)

Class Bivalvia

Subclass Palaeotaxodonta

Order Nuculoida

Nuculana pernula (Müller 1776)
Yoldiella lenticula (Möller 1842)

Subclass Pteriomorpha

Order Mytiloida

Musculus laevigatus (Gray 1824)

Musculus niger (Gray 1824)

Subclass Heterodonta

Order Veneroida

Axinopsida orbiculata (G.O. Sars 1878)

Tridonta borealis Schumacher 1817

Macoma calcarea (Gmelin 1791)

total for Climatic regions asb. : 13 (37.1\%)

Climatic regions: asbl

Class Gastropoda

Subclass Prosobranchia

Order Neotaenioglossa

Littorina saxatilis (Olivi 1792)

Natica affinis (Gmelin 1790)

Subclass Opisthobranchia

Order Bullomorpha Cylichna alba (Brown 1827)

Order Thecosomata

Limacina retroversa (Fleming 1823)

Class Bivalvia

Subclass Palaeotaxodonta

Order Nuculoida

Nuculoma tenuis (Montagu 1808)

Subclass Heterodonta

Order Veneroida Thyasira flexuosa (Montagu 1803)

Order Myoida Mya truncata Linnaeus 1758

Hiatella arctica (Linnaeus 1758)

Total for climatic regions asbl: 8 (22.9\%)

Climatic regions: .sb.

Class Bivalvia

Subclass Pteriomorpha

Order Pterioida

Chlamys islandica (O.F. Müller 1776)

Subclass Heterodonta

Order Veneroida

Arctica islandica (Linnaeus 1767)

Order Myoida

Zirfaea crispata (Linnaeus 1758)

Total for climatic regions .sb. : 3 (8.6\%)

Climatic regions: .sbl

Class Polyplacophora

Order Neoloricata 


\author{
Tonicella marmorea (Fabricius 1780) \\ Class Gastropoda \\ Subclass Prosobranchia \\ Order Neotaenioglossa \\ Lacuna vincta (Montagu 1803) \\ Order Neogastropoda \\ Buccinum undatum Linnaeus 1758 \\ Class Bivalvia \\ Subclass Pteriomorpha \\ Order Mytiloida \\ Mytilus edulis Linnaeus 1758 \\ Subclass Heterodonta \\ Order Veneroida \\ Macoma balthica (Linnaeus 1758)
}

Total for climatic regions .sbl: 5 (14.3\%)

The Late Weichselian Vendsyssel: 35 (14.2\%)

Marine molluscs from the time after the main glaciation of Denmark have been recorded only from Vendsyssel and Skagen, but new studies are increasing our knowledge from the Kattegat region, but are not included in this work.

The marine mollusc assemblages in Vendsyssel have been mainly based on open profiles. The recorded mollusc species amount to 35 . However, there are some problems in classifying the whole fauna in communities.

Three climatic groups can be demonstrated: a purely Arctic and Subarctic with six species, an Arctic, Subarctic and Boreal consisting of 13 species, and a group of species which does not enter the Arctic but might be found extending into the Lusitanian. A fourth group with a wide range can be differentiated according to depth ranges. Littorina saxatilis is intertidal, while Natica affinis, Cylichna alba, and Thyasira flexuosa are species found from infratidal to great depths. Nuculoma tenuis is found offshore to $300 \mathrm{~m}$, and Limacina retroversa is pelagic.

So the species with a climatically wide range show the existence of two facies: a littoral and a deeperwater facies.

Considering the five species with a representation within the Subarctic, Boreal and Lusitanian regions, Macoma balthica is a shallow-water species, Mytilus edulis is eulittoral and here the species occurs in great quantities, Lacuna vincta is intertidal to depths of 60 $\mathrm{m}$, Tonicella marmorea from 0 to $183 \mathrm{~m}$ but more common at depths of less than $20 \mathrm{~m}$, and finally Buccinum undatum which is found sublittorally to great depths (1200 m).

The characteristic depth for the dominating part of these molluscs is seen to be the shallow water.

Two of the species from the Subarctic-Boreal group, Arctica islandica and Zirfaea crispata, have very different characteristics as to depth of living. The depth range for Arctica islandica is in general intertidal to 480 m, but Jensen (1902, pp. 38-39) writes that Arctica is a genuine Boreal species and bases this on the fact that in the White Sea area, which is in the northernmost part of its distribution, it is found in more shallow water than elsewhere. A relatively high temperature is reached only in the shallow water in this region.

This means that Arctica islandica in the present setting among other molluscs of purely Arctic and Subarctic relations must be an indicator of Boreal waters in the shallow-water environment. Zirfaea crispata is on the other hand a clear indicator of shallow water, having its range of depth between the low tide line and out to a depth of about $7 \mathrm{~m}$.

The third member of the Subarctic-Boreal climatic region, Chlamys islandica, is known from the tidal zone and down to depths of $300 \mathrm{~m}$.

Of the 13 species represented within the climatic regions of the Arctic, Subarctic and Boreal, half of the members are infralittoral from 6-10 $\mathrm{m}$ to great depths: Lunatia pallida, Boreotrophon clathratus, Neptunea despecta, Oenopota turricola, Nuculana pernula, Yoldiella lenticula, and Musculus niger. The other half can be found in the tidal zone but also at greater depths. Among these, Macoma calcarea and Tridonta borealis are the characteristic bivalves in the Arctic shallowwater Macoma calcarea community with the Astarte borealis zone in the most shallow parts from 3 to about 12-14 m in East Greenland (Thorson 1933, pp. 8-18). According to Thorson (1933), the Astarte borealis zone is no tide-water community such as for instance the Macoma balthica community in some Boreal seas. This is discussed in further detail by Madsen (1936, p. 71), who concludes: "The littoral fauna [north of $c .66-67^{\circ} \mathrm{N}$ lat. East Greenland] is especially characterised by the absence of littoral molluscs and Balanidea, notably Mytilus edulis, Littorina saxatilis var. groenlandica, and Balanus balanoides, all of which occur south of the above-mentioned limit".

The Arctic-Subarctic species in Vendsyssel, represented by four species, can be found at water depths from 2 to $5 \mathrm{~m}$ and out to around $200 \mathrm{~m}$, except Cylichna occulta, which has a depth range of from $20 \mathrm{~m}$ to nearly $400 \mathrm{~m}$.

The purely Arctic species Portlandia arctica and Macoma torelli are recorded from 2 and $5 \mathrm{~m}$ out to 
around $340 \mathrm{~m}$ and $90 \mathrm{~m}$ respectively. This shows that the Arctic-Subarctic part of the recorded species from the Vendsyssel region have a wide range of occurrence restricted not by a single species to the shallowwater environment as is the case among the more temperate mollusca and the species with a wide climatic range: Arctica islandica, Zirfaea crispata, Macoma balthica, Mytilus edulis, and Littorina saxatilis.

It can therefore be stated that all the Arctic species could be together in deeper water and some also in the more shallow water. However, some of the more temperate species are restricted to shallow water, and Arctica islandica is a distinctly shallow-water species in the northern part of its range. So, within the time span of deposition for the Late Weichselian Younger Yoldia Sea deposits, an amelioration of the shallowwater environment including the tidal zone must have happened.

Nordmann (1910) noticed that certain marine strata in the Vendsyssel region had a distinct littoral fauna, and he suggested that these beds were of a more recent origin than the Younger Yoldia Clay, introducing the so-called Zirphaea transgression named after one of the characteristic bivalves from the shallow-water environment discussed above. However, Petersen (1984), on the basis of molluscan studies combined with the many ${ }^{14} \mathrm{C}$ dates, could conclude that the deposition of Yoldia Clay containing a cold marine fauna from deeper water is seen to continue into Bølling, but with a contemporaneous temperate fauna in the shallow-water deposits - the Zirphaea Beds. The evaluation of the marine history from Vendsyssel is highly influenced by experiences obtained from work on Holocene raised marine deposits and recent bottom samples in East Greenland, as seen in Petersen (1986b, figs 2, 3), where beds from the Astarte borealis zone with Mytilus edulis are overlying the Ophiocten zone (deeper part of the Arctic Macoma calcarea community (Thorson 1933, pp. 18-27)) with Portlandia arctica. These observations may also explain the occurrences of redeposited material mentioned within the discussion of the Older Yoldia Clay at Skærumhede in the Vendsyssel region. Still, it must be regarded as redeposited, but not necessarily differing so much in time, as long as the above-mentioned observations show that a more temperate zone can be found in the shallow-water environment contemporaneous with an Arctic fauna in deeper water.

\section{Skagen}

\author{
Age: Late Weichselian \\ Climatic regions: a... \\ Class Bivalvia \\ Subclass Palaeotaxodonta \\ Order Nuculoida \\ Portlandia arctica (Gray 1824) \\ Total for climatic regions a... : 1 (11.1\%) \\ Climatic regions: as.. \\ Class Bivalvia \\ Subclass Pteriomorpha \\ Order Arcoida \\ Batbyarca glacialis (Gray 1824) \\ Total for climatic regions as.. : 1 (11.1\%)

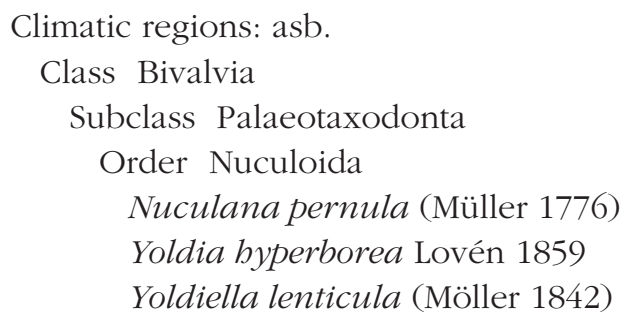

Climatic regions: asb.

Class Bivalvia

Subclass Palaeotaxodonta

Order Nuculoida

Nuculana pernula (Müller 1776)

Yoldia hyperborea Lovén 1859

Yoldiella lenticula (Möller 1842)

Total for climatic regions asb. : 3 (33.3\%)

Climatic regions: asbl
Class Gastropoda
Subclass Opisthobranchia
Order Gymnosomata
Clione limacina (Phipps 1774)
Class Scaphopoda
Siphonodentalium lobatum (Sower
Class Bivalvia
Subclass Palaeotaxodonta
Order Nuculoida
Yoldiella frigida (Torell 1859)
Total for climatic regions asbl: 3 (33.3\%)
Climatic regions: .sb.
Class Bivalvia
Subclass Palaeotaxodonta
Order Nuculoida
Nuculana minuta (Müller 1776)
Total for climatic regions .sb. : 1 (11.1\%)

The Late Weichselian Skagen: 9 (3.6\%)

The Skagen region has contributed with only nine species, out of which the Clione limacina species must be taken with some reservation, being based on an 
imprint only. All the recorded species have been taken from the Skagen Well core superjacent to the older Eemian and Weichselian deposits discussed above. Therefore the fauna represents an assemblage from a certain depth - through time - and can be seen in relation to the sedimentological information (Appendix 3). The granulometric composition in the Older Yoldia Sea sequence reflects two maxima on the frequency curve, which tells that part of the material, other than the extremely fine-grained, can be taken as icerafted material. However, no such redeposited material was found in the fauna. The whole mollusc assemblage resembles the Arca-Astarte crenata community as described by Thorson (1934) from Hurry Inlet, East Greenland.

First of all the Arca glacialis (Bathyarca glacialis) is represented among the molluscs recorded from the Skagen Well. This species is one of the characteristic species from this community. Furthermore, the following species are mentioned (Thorson 1934, p. 48): Siphonodentalium vitreum (S. lobatum), Leda pernula (Nuculana p.), Portlandia arctica, Portlandia lenticula (Yoldiella l.), Portlandia frigida (Yoldiella f.), and Saxicava arctica (Hiatella $a$.) which have all been recorded from the Skagen Well. Only Nuculana minuta, a Subarctic-Boreal species, and Yoldia hyperborea are not recorded from Hurry Inlet. Ockelmann (1958, pp. 19-22) mentioned that Nuculana minuta is "lacking in the most high-Arctic seas" and that according to Thorson (1934) Yoldia byperborea is associated with calm, sheltered places, and besides Yoldia hyperborea is otherwise known from only a few places in East Greenland.

These records from Greenland demonstrate a good agreement with the Danish Late Weichselian finds from the Skagen Well and permit further comparison with the Arca-Astarte crenata community. According to Thorson (1933, p. 67), this community inhabits depths from ca. 45 to ca. $200 \mathrm{~m}$. Furthermore, it is poor in species, and the temperature is negative and constant all the year round.

The well-dated strata of Late Weichselian age, from $15000-10000$ before present in ${ }^{14} \mathrm{C}$ years, around 17000 - 11000 in calibrated age B.P. (see Appendix 4) in the Skagen Well have no influence from the shallow-water Boreo-Arctic assemblage as found in the Vendsyssel region around 13000 before present (Petersen 1984, p. 65), but reveal with their Arctic deeperwater mollusc fauna a sharp boundary to the Holocene Boreo-Lusitanian faunas.

\section{Holocene species sorted after climatic affinities}

The boundary between the Pleistocene and the Holocene marine strata as seen in the Skagen Well is unique within the Danish realm. Furthermore, the approximately $115 \mathrm{~m}$ of Holocene marine beds as described earlier represent a well-dated sequence to be compared to the other Holocene marine finds recorded in the six regions, many of which offer dated strata as well. The following description will proceed in the same way as taken for the marine Pleistocene strata, and it will present the entire molluscan fauna from each region from the point of view of climatic affinities for each species, with subsequent comments upon certain aspects for selected species.

Within each region, reference to well-dated strata and their molluscan assemblages will be given and worked out to facilitate the correlation in time to assemblages in other regions.

Finally, the juncture of occurrence during the Holocene of some of the molluscan species in all regions can be estimated, as presented in Appendix 6.

\section{The Bælt Sea}

Climatic regions: asb

Class Gastropoda

Subclass Opisthobranchia

Order Anaspidea

Retusa obtusa (Montagu 1803)

Class Bivalvia

Subclass Heterodonta

Order Veneroida

Tridonta borealis Schumacher 1817

Total for climatic regions asb. : 2 (4.3\%)

Climatic regions: asbl

Class Gastropoda

Subclass Prosobranchia

Order Neotaenioglossa

Littorina saxatilis (Olivi 1792)

Lacuna pallidula (da Costa 1778)

Class Bivalvia

Subclass Pteriomorpha

Order Mytiloida

Musculus discors (Linnaeus 1767)

Subclass Heterodonta

Order Myoida

Mya truncata Linnaeus 1758

Hiatella arctica (Linnaeus 1758) 
Total for climatic regions asbl: 5 (10.6\%)

Climatic regions: .sb.

Class Bivalvia

Subclass Heterodonta

Order Veneroida

Arctica islandica (Linnaeus 1767)

Order Myoida

Zirfaea crispata (Linnaeus 1758)

Total for climatic regions .sb. : 2 (4.3\%)

Climatic regions: .sbl

Class Gastropoda

Subclass Prosobranchia

Order Neotaenioglossa

Littorina obtusata (Linnaeus 1758)

Lacuna vincta (Montagu 1803)

Onoba semicostata (Montagu 1803)

Subclass Heterobranchia

Order Heterostropha

Omalogyra atomus (Phillippi 1841)

Class Bivalvia

Subclass Pteriomorpha

Order Mytiloida

Mytilus edulis Linnaeus 1758

Modiolus modiolus (Linnaeus 1758)

Subclass Heterodonta

Order Veneroida

Mysella bidentata (Montagu 1803)

Parvicardium ovale (Sowerby 1840)

Macoma balthica (Linnaeus 1758)

Total for climatic regions .sbl: 9 (19.1\%)

Climatic regions: ..b.

Class Bivalvia

Subclass Heterodonta

Order Myoida

Mya arenaria Linnaeus 1758

Total for climatic regions ..b. : 1 (2.1\%)

Climatic regions: ..bl

Class Gastropoda

Subclass Prosobranchia

Order Neotaenioglossa

Littorina littorea (Linnaeus 1758)

Littorina tenebrosa (Montagu 1803)

Hydrobia ulvae (Pennant 1777)

Hydrobia ventrosa (Montagu 1803)

Rissoa albella Lovén 1846

Rissoa inconspicua Alder 1844

Rissoa membranacea (J. Adams 1800)
Bittium reticulatum (da Costa 1778)

Order Heterogastropoda

Triphora adversa (Montagu 1803)

Order Neogastropoda

Hinia reticulata (Linnaeus 1758)

Subclass Heterobranchia

Order Heterostropha

Odostomia conoidea Winckworth 1932

Subclass Opisthobranchia

Order Anaspidea

Retusa truncatula (Bruguière 1792)

Akera bullata Müller 1776

Subclass Pulmonata

Order Basommatophora Lymnaea peregra (Müller 1774)

Class Bivalvia

Subclass Pteriomorpha

Order Mytiloida Modiolula phaseolina (Philippi 1844)

Order Pterioida

Subclass Heterodonta

Order Veneroida

Parvicardium exiguum (Gmelin 1791)

Parvicardium scabrum (Philippi 1844)

Cerastoderma edule (Linnaeus 1758)

Spisula subtruncata (da Costa 1778)

Angulus tenuis (da Costa 1778)

Scrobicularia plana (da Costa 1778)

Abra alba (Wood 1802)

Paphia aurea (Gmelin 1791)

Tapes decussatus (Linnaeus 1758)

Venerupis pullastra (Montagu 1803)

Order Myoida

Corbula gibba (Olivi 1792)

Barnea candida (Linnaeus 1758)

Total for climatic regions ..bl: 28 (59.6\%)

The Holocene Bæelt Sea: 47 (19.0\%)

The Holocene molluscs in the Bælt Sea region amount to 47 mainly Boreo-Lusitanian species. There are no purely Lusitanian species, only two Arctic-Subarctic and Boreal species, and five species with a wide range of distribution. This is a clear difference compared to the Eemian molluscan fauna from the same region with no less than seven purely Lusitanian species.

This is not connected with differences in depth ranges. All of the subfossil species from the Holocene could be found within the intertidal zone except: Odostomia conoidea and Parvicardium ovale occur- 
ring below 5-10 m, or infratidal species such as Tridonta borealis, Modiolus modiolus and Abra alba. Abra alba characterises the Bælt Sea deeper-water community and Tridonta borealis the community in the Baltic, the so-called Abra alba and Astarte communities sensu Petersen (1913, p. 16).

The overall dominating part of the species could be associated with the Macoma community sensu Petersen (1913, p. 14) which nowadays is recorded from the fjords and the more sheltered coasts from the shore and out to a depth of 10-12 m. This community is named after Macoma balthica, also present in the Bælt Sea subfossil molluscan fauna. The great similarity between the subfossil Holocene fauna and the recent, as seen from the above-mentioned dates on the communities met with, is also revealed in the present distribution of the species in question. Almost all the species occur in the present-day Bælt Sea or even further into the Baltic region - east of Darss. The few species no longer found in the Brelt Sea region are: Littorina saxatilis, Odostomia conoidea, Modiolula phaseolina, Ostrea edulis, Parvicardium scabrum, Angulus tenuis and Venerupis pullastra which only extend into the Kattegat region today, while Paphia aurea, Tapes decussatus, and Omalogyra atomus are no longer recorded in the Danish mollusc fauna.

The absence of certain species is most likely an effect of the salinity reached in the Bælt Sea at present. However, as mentioned by Rasmussen (1973, p. 303) in the case of Venerupis pullastra, the distribution might be connected with the bottom conditions (see the chapter on molluscan species). Most of the species now absent from the Bælt Sea were present during the Atlantic, and, in all, 31 molluscan species have their first appearance in this period (Appendix 6).

Among the 31 species with dated appearances in the Atlantic, Littorina saxatilis and Mya truncata have a wide climatic range. Arctica islandica is found in the Boreal region, and Lacuna vincta, Onoba semicostata, Mytilus edulis, Mysella bidentata, and Macoma balthica are Subarctic-Boreal-Lusitanian. The rest of the species appearing in the Atlantic amount to 23 species with dated appearances during the Atlantic within the Brelt Sea area.

The 31 species constitute $12.6 \%$ of the known subfossil molluscan finds from the Late Quaternary, while the total finds of molluscs from the Holocene Bæelt Sea represent $19.0 \%$ (47 species out of the 247 subfossil species).

This might indicate that the more prolific fauna in the Brelt Sea was connected with a time interval when the inner Danish waters were still affected by a higher tidal impact which expired at the beginning of the Subboreal (Petersen 1993).

However, Paphia aurea and Ostrea edulis are still met with as food elements, although rather rare, in the Iron Age 'køkkenmøddinger' (kitchen middens) in the western part of the Bælt Sea (Petersen 1985c, fig. 5, p. 22). Mya arenaria has been found in the Bælt Sea embedded in strata from the Atlantic. The appearance of this species within the Atlantic strata is explained by the deep-burrowing habit of this infauna species. However, the first appearance of the species must be referred to the Subatlantic after new dates in the Bælt Sea region following the study of the immigration of Mya arenaria to Danish waters (Petersen et al. 1992b).

\section{The Baltic}

Climatic regions: .sbl

Class Bivalvia

Subclass Pteriomorpha

Order Mytiloida

Mytilus edulis Linnaeus 1758

Subclass Heterodonta

Order Veneroida

Macoma balthica (Linnaeus 1758)

Total for climatic regions .sbl: 2 (10.5\%)

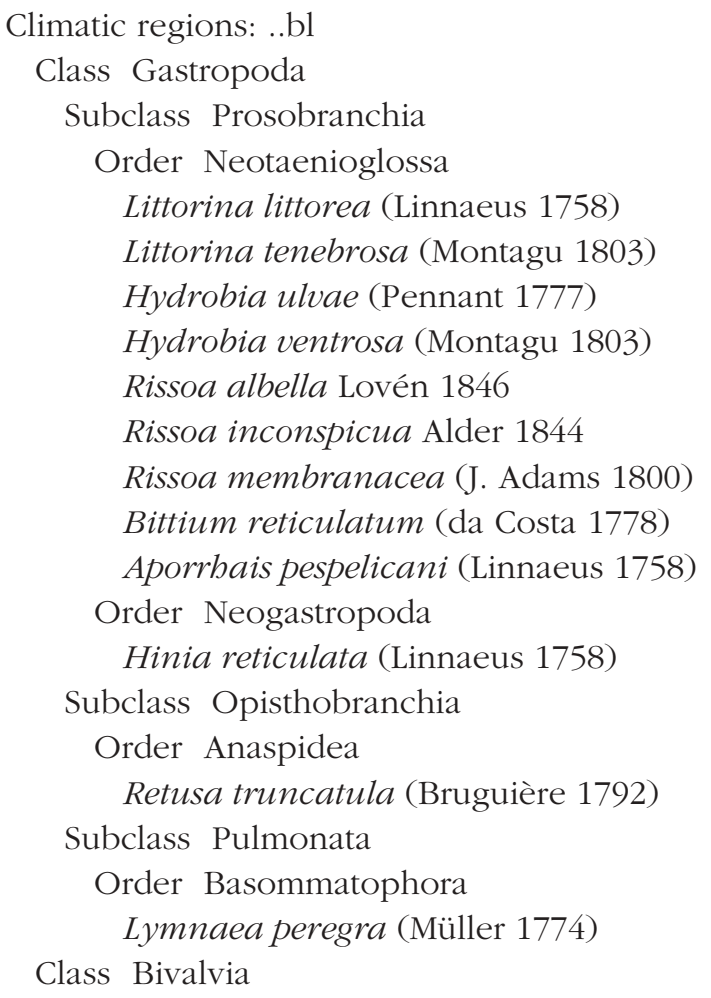

Class Bivalvia 


\author{
Subclass Heterodonta \\ Order Veneroida \\ Parvicardium exiguum (Gmelin 1791) \\ Cerastoderma edule (Linnaeus 1758) \\ Cerastoderma glaucum (Poiret 1798) \\ Scrobicularia plana (da Costa 1778) \\ Order Myoida \\ Corbula gibba (Olivi 1792)
}

Total for climatic regions ..bl: 17 (89.5\%)

The Holocene Baltic: 19 (7.7\%)

Among the 19 species recorded from the Holocene of the Baltic, there is relatively many, which do not occur in the recent Baltic fauna, viz.: Rissoa albella, Rissoa inconspicua, Bittium reticulatum, Hinia reticulata, Retusa truncatula, and Scrobicularia plana, but they are present in the neighbouring recent Bxlt Sea fauna. Furthermore, Aporrhais pespelicani can be added which today extends into the Kattegat region, while only empty shells have been recorded from the Bælt Sea region off Kiel (Arntz et al. 1976).

So, although the spectacular oyster and Tapes species did not occur as in the Bælt Sea, the subfossil Baltic fauna has quite a few species that no longer live in the Baltic. The geological mapping from this region (Milthers 1908) does not provide further information on the chronostratigraphic position of these mollusc species, and is also rather poor, since they are based on samples from near present-day sea level.

This is also corroborated by Munthe (1894, p. 9): "in the south part of the Baltic region we possess but comparatively little knowledge of the fauna which results partly from the circumstances that the Litorina strata are here to be sought only to a small extent above the sea level". This has obviously hampered the study within the Danish region, so that Holocene marine deposits in the Baltic are little known up to the present. However, recent activities by marine geologists have given new material from the westernmost part of the Baltic - Fakse Bugt (Jensen 1995). As far as the mollusc studies have been submitted (Petersen 1994b) but not published in detail, the following comments will be given to Fig. 101.

The $4 \mathrm{~m}$ of sampling from vibrocore $225 \mathrm{~B}$ comes from the cored section $17.5-13.5 \mathrm{~m}$ b.s.l. and has been dated within a time span of $4000{ }^{14} \mathrm{C}$ years covering the early part of the Holocene from the Preboreal to the Atlantic, through time represented by freshwater, brackish and marine deposits as deduced from the occurrences of mollusc.

The loss on ignition shows that the lower third of the sequence has around 25 weight per cent of organic material, while the upper two-thirds of the sequence has less than 5 weight per cent loss on ignition (Fig. 101).

Considering the mollusc species, it appears that the high amount of organic material is not connected solely with the freshwater deposits, but continues into the brackish-water layers.

The first rise of sea level is demonstrated by the occurrences of Cerastoderma and Mytilus and the disappearance of the freshwater molluscs such as Valvata macrostoma and the Sphaeriidae. The persistent occurrence of the Bithynia tentaculata operculae in the oldest part of the brackish-water deposits shows that salinity was lower than $12 \%$.

Within this interval, seven mollusc species occur (see Fig. 101), viz.: two Hydrobia and one Rissoa species and the bivalves Mytilus, Macoma and Cerastoderma. The Cerastoderma species are rather difficult to identify in all the samples because of their poor state of preservation.

At a level of about $15.5 \mathrm{~m}$ b.s.l., the change to higher diversity of marine molluscs occurs with such new species as Aporrhais pespelicani, Nassarius reticulatus and Scrobicularia plana besides the steady occurrence of Littorina littorea, Retusa truncatula and Corbula gibba. Even Bittium reticulatum has been found in one sample. This species tolerates only water with a salinity above 25\% (Sorgenfrei 1958). In all circumstances the more prolific marine fauna is well demonstrated in this part of the sequence, and furthermore, single occurrences of species such as Rissoa membranacea, Lacuna vincta, and Parvicardium exiguum sustain this view. The occurrence of freshwater gastropods is a product of transport from the nearby land, where freshwater streams run into the bay or may be eroded from older deposits by currents. In the topmost part of the core especially fishbones occur up to the present sea bottom at $13.5 \mathrm{~m}$ b.s.l.

The faunal development in the $4 \mathrm{~m}$ core reflects as the oldest element a small lake dated to the time span $9370 \pm 135$ (K-5649) up to $7900 \pm 115(\mathrm{~K}-5652)$ in ${ }^{14} \mathrm{C}$ years B.P. Around 7900 B.P. the marine influence is found at the present level of $16.5 \mathrm{~m}$ b.s.l. with the establishment of a brackish-water fauna. At a level of $15.30 \mathrm{~m}$ b.s.l., which has been dated to $6520 \pm 135{ }^{14} \mathrm{C}$ years B.P. (AAR-633), the change to the more prolific Littorina Sea fauna has taken place. But, the samples 


\section{The occurrences of molluscan species in the Fakse Bugt Well}
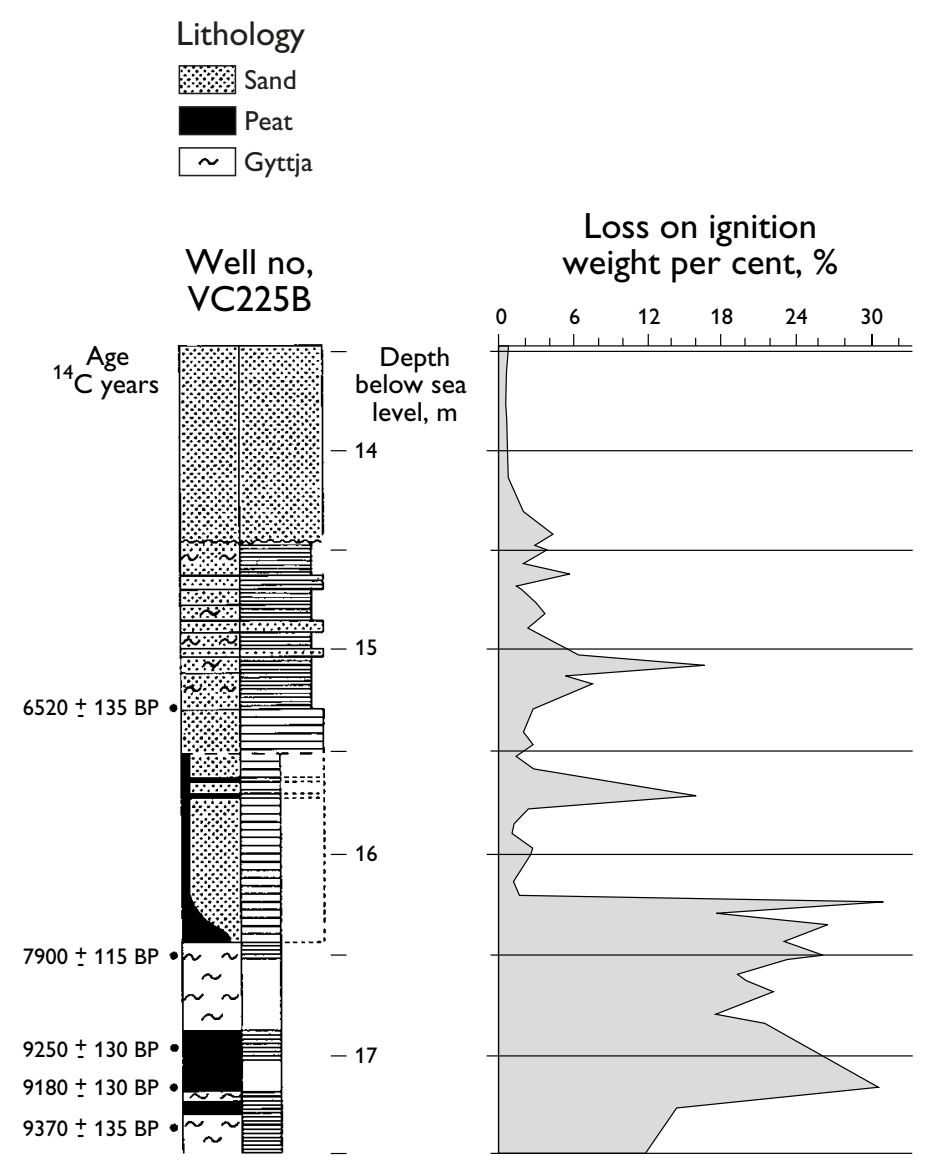

\section{Molluscan species with their salinity tolerances}
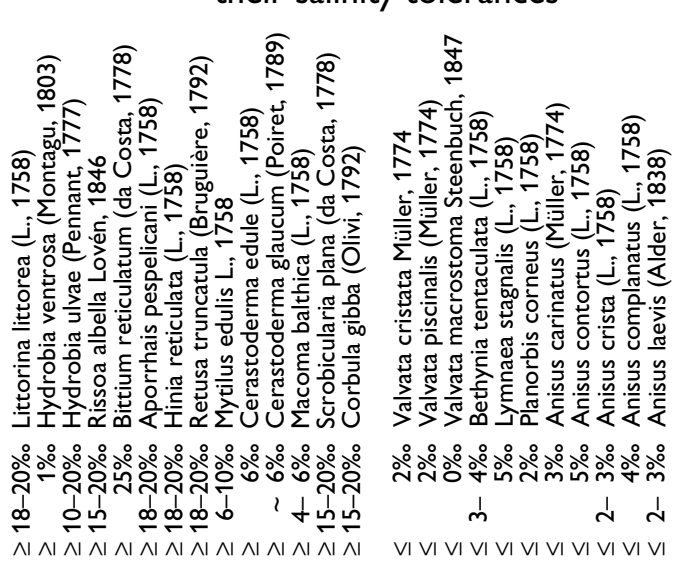

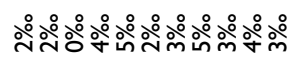

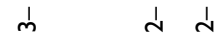

VI VI VI VIVIVIVIVIVIVIVI

Fig. 101. The occurrences of molluscan species in the Fakse Bugt Well no. VC225B with indication of loss on ignition and sedimentary log with datings $\left({ }^{14} \mathrm{C}\right.$ years) based on Jensen (1995).

from higher up in the core do not show any development into the present-day molluscan fauna, first of all because of the absence of Mya arenaria that characterises the present-day Baltic Sea.

In conclusion, the Littorina Sea fauna from the Fakse Bugt as demonstrated from this core is from the Atlantic and shows the molluscs of the transgression around 8000 B.P. $\left({ }^{14} \mathrm{C}\right.$ years $)$ and the established marine fauna of the Atlantic.

The fauna from this core contains most of the abovementioned species no longer found in the Baltic, and it is shown that this fauna was most probably established during the Atlantic. Therefore, the marine molluscs from the cored section immigrated to the Baltic during the Atlantic (Appendix 6).

Among the 15 species with dated appearances in the Atlantic only Mytilus edulis and Macoma baltbica have their climatic range within the Subarctic-BorealLusitanian regions, while the rest belong to the BorealLusitanian group as in the Bælt Sea area. However, the number of mollusc species from this region is very low with the 19 species found forming only $7.7 \%$ of the subfossil fauna.

As in the case of the Bælt Sea, the more prolific fauna can be connected with the Atlantic, and this could be caused by the higher tidal amplitude during this time span giving a higher salt content.

In the introduction it was mentioned that there is 
no record of mollusc species from the geological mapping of the island of Bornholm (Grönwall \& Milthers 1916). Several bottom samples have been analysed from east of Bornholm by the author, showing large amounts of Tridonta elliptica and Tridonta borealis, but the material was never dated, so they could be subrecent specimens. They have therefore not been included in the present list of subfossil Holocene molluscs from the Baltic.

\section{The Kattegat}

Climatic regions: asb.

Class Gastropoda

Subclass Opisthobranchia

Order Anaspidea

Retusa obtusa (Montagu 1803)

Total for climatic regions asb. : 1 (2.2\%)

Climatic regions: asbl

Class Gastropoda

Subclass Prosobranchia

Order Neotaenioglossa

Littorina saxatilis (Olivi 1792)

Class Bivalvia

Subclass Pteriomorpha

Order Mytiloida

Musculus discors (Linnaeus 1767)

Subclass Heterodonta

Order Myoida

Mya truncata Linnaeus 1758

Hiatella rugosa (Linnaeus 1758)

Total for climatic regions asbl: 4 (8.9\%)

Climatic regions: .sb.

Class Bivalvia

Subclass Heterodonta

Order Veneroida

Arctica islandica (Linnaeus 1767)

Total for climatic regions .sb. : 1 (2.2\%)

Climatic regions: .sbl

Class Gastropoda

Subclass Prosobranchia

Order Neotaenioglossa

Littorina obtusata (Linnaeus 1758)

Lacuna vincta (Montagu 1803)

Skeneopsis planorbis (Fabricius 1780)

Onoba semicostata (Montagu 1803)

Order Neogastropoda
Buccinum undatum Linnaeus 1758

Subclass Heterobranchia

Order Heterostropha

Omalogyra atomus (Phillippi 1841)

Class Bivalvia

Subclass Pteriomorpha

Order Mytiloida

Mytilus edulis Linnaeus 1758

Order Pterioida

Heteranomia squamula (Linnaeus 1758)

Subclass Heterodonta

Order Veneroida

Mysella bidentata (Montagu 1803)

Macoma baltbica (Linnaeus 1758)

Total for climatic regions .sbl: 10 (22.2\%)

Climatic regions: ..b.

Class Bivalvia

Subclass Heterodonta

Order Myoida

Mya arenaria Linnaeus 1758

Total for climatic regions ..b. : 1 (2.2\%)

Climatic regions: ..bl

Class Gastropoda

Subclass Prosobranchia

Order Archaeogastropoda

Theodoxus fluviatilis (Linnaeus 1758)

Order Neotaenioglossa

Littorina littorea (Linnaeus 1758)

Littorina tenebrosa (Montagu 1803)

Hydrobia ulvae (Pennant 1777)

Hydrobia ventrosa (Montagu 1803)

Onoba vitrea (Montagu 1803)

Rissoa albella Lovén 1846

Rissoa inconspicua Alder 1844

Rissoa membranacea (J. Adams 1800)

Bittium reticulatum (da Costa 1778)

Order Heterogastropoda

Triphora adversa (Montagu 1803)

Order Neogastropoda

Hinia reticulata (Linnaeus 1758)

Subclass Heterobranchia

Order Heterostropha

Brachystomia eulimoides Hanley 1844

Chrysallida spiralis (Montagu 1803)

Subclass Opisthobranchia

Order Anaspidea

Retusa truncatula (Bruguière 1792)

Akera bullata Müller 1776

Class Bivalvia 


\author{
Subclass Pteriomorpha \\ Order Pterioida \\ Ostrea edulis Linnaeus 1758 \\ Subclass Heterodonta \\ Order Veneroida \\ Acanthocardia echinata (Linnaeus 1758) \\ Parvicardium exiguum (Gmelin 1791) \\ Parvicardium scabrum (Philippi 1844) \\ Cerastoderma edule (Linnaeus 1758) \\ Cerastoderma glaucum (Poiret 1798) \\ Scrobicularia plana (da Costa 1778) \\ Abra alba (Wood 1802) \\ Paphia aurea (Gmelin 1791) \\ Tapes decussatus (Linnaeus 1758) \\ Venerupis pullastra (Montagu 1803) \\ Order Myoida \\ Corbula gibba (Olivi 1792)
}

Total for climatic regions ..bl: 28 (62.2\%)

The Holocene Kattegat: 45 (18.2\%)

The molluscs from the Kattegat region have to a great extent been collected in the raised marine forelands to the Kattegat itself during the geological mapping in contrast to some of the sampling localities referred to in the preceding two regions. So, although part of the information from Djursland comes from borings to a depth of about $10 \mathrm{~m}$ b.s.l., it does not present deeperwater deposits as met with in the Kattegat proper (Petersen 1993). This is also true of the maximum palaeodepth reached, when it is taken into account that the present area is within the isostatic uplift zone with the highest marine shoreline - up to about $10 \mathrm{~m}$ - within this region (Mertz 1924).

Forty-five mollusc species have been recorded from the Kattegat region. There are no purely Lusitanian species, but Boreo-Lusitanian species. Reflecting the above-mentioned facts on maximum palaeodepth, all the species can be found within the tidal/shallow-water zone, viz.: Littorina saxatilis, Littorina obtusata, Littorina tenebrosa, Hydrobia ulvae, Theodoxus fluviatilis, Mytilus edulis, Cerastoderma edule, and Tapes decussatus. Tapes decussatus and Paphia aurea are no longer found in Danish waters, but occur off western and southern Norway in the immediate neighbourhood. Rørdam (1891) discussed at some length the different mollusc assemblages in north-eastern Sjælland and related these faunas to their relative positions from the open sea and into the innermost part of the fjords. Petersen (in Rørdam 1891, pp. 106-111), who deter- mined most of the molluscan species in Rørdam's thesis (Rørdam 1891, p. 106), stated that: "The deposition of the Tapes layers has happened in a period where the Danish waters from a hydrographical point of view have been more like the North Sea or the open sea than now".

This was clearly demonstrated by the large oyster banks present far into the Roskilde Fjord in north-eastern Sjælland, and it has also been recorded from other mapped areas on Fyn and in Jylland. The innermost part of the former fjords always carried a rich subfossil mollusc fauna compared to the recent fjord complexes. Recent studies from Jylland of the faunal changes through time have shown that the rich faunas in the innermost part of such fjord regions developed during the Atlantic. This situation is most probably connected with a higher tidal amplitude in the inner Danish waters during the Atlantic than in the following Subboreal period, as argued in Petersen (1993).

The absence of purely Lusitanian species in the midHolocene fauna from the Kattegat region shows, as mentioned above, that climatic changes have not been of major significance. The most characteristic species for the Holocene subfossil fauna in this region - the Tapes species - is still to be found within the Boreal region.

Of the 25 dated molluscan species from Djursland, 23 species have immigrated during the Atlantic along with the transgression (Petersen 1993, table 1). Only two species, Littorina tenebrosa and Onoba semicostata, immigrate after the change to more brackish-water conditions that prevailed in the Subboreal. Among the species with a dated appearance in the Atlantic, which form nearly half of the mollusc species known from this region, the dominating climatic group is the Boreo-Lusitanian, with 18 species.

The whole fauna of 45 species from the Kattegat region constitutes $18.2 \%$ of the subfossil molluscs. This is close to the percentage for the Bxlt Sea area but much less than could be expected regarding the number of species from the recent Kattegat region. This recalls the above-mentioned fact that the sampling of the molluscan material has been from raised marine forelands and therefore does not include the deeperwater fauna from the vast area of the Kattegat proper. However, as mentioned earlier in connection with the Late Weichselian marine deposits, new studies are progressing recording the deeper-water fauna with, inter alia, Turritella communis from the Kattegat during the Holocene. 


\section{The Limfjord}

Climatic regions: asb.

Class Gastropoda

Subclass Prosobranchia

Order Archaeogastropoda

Margarites belicinus (Phipps 1774)

Order Neogastropoda

Oenopota turricola (Montagu 1803)

Subclass Opisthobranchia

Order Anaspidea

Retusa obtusa (Montagu 1803)

Class Bivalvia

Subclass Heterodonta

Order Veneroida

Tridonta borealis Schumacher 1817

Total for climatic regions asb. : 4 (2.7\%)

Climatic regions: asbl

Class Gastropoda

Subclass Prosobranchia

Order Archaeogastropoda

Acmaea tessulata (Müller 1776)

Order Neotaenioglossa

Littorina saxatilis (Olivi 1792)

Lacuna pallidula (da Costa 1778)

Subclass Opisthobranchia

Order Bullomorpha

Cylichna alba (Brown 1827)

Order Anaspidea

Diaphana minuta Brown 1827

Class Bivalvia

Subclass Palaeotaxodonta

Order Nuculoida

Nuculoma tenuis (Montagu 1808)

Subclass Pteriomorpha

Order Mytiloida

Musculus discors (Linnaeus 1767)

Subclass Heterodonta

Order Veneroida

Thyasira flexuosa (Montagu 1803)

Order Myoida

Mya truncata Linnaeus 1758

Hiatella arctica (Linnaeus 1758)

Total for climatic regions asbl: 10 (6.8\%)

Climatic regions: .sb.

Class Bivalvia

Subclass Heterodonta

Order Veneroida

Arctica islandica (Linnaeus 1767)

Order Myoida
Zirfaea crispata (Linnaeus 1758)

Total for climatic regions .sb. : 2 (1.4\%)

Climatic regions: .sbl

Class Gastropoda

Subclass Prosobranchia

Order Archaeogastropoda

Acmaea virginea (Müller 1776)

Order Neotaenioglossa

Littorina obtusata (Linnaeus 1758)

Lacuna vincta (Montagu 1803)

Skeneopsis planorbis (Fabricius 1780)

Onoba semicostata (Montagu 1803)

Order Neogastropoda

Nucella lapillus (Linnaeus 1758)

Buccinum undatum Linnaeus 1758

Subclass Heterobranchia

Order Heterostropha Omalogyra atomus (Phillippi 1841)

Class Bivalvia

Subclass Pteriomorpha

Order Mytiloida

Mytilus edulis Linnaeus 1758

Modiolus modiolus (Linnaeus 1758)

Order Pterioida

Delectopecten vitreus (Gmelin 1791)

Heteranomia squamula (Linnaeus 1758)

Subclass Heterodonta

Order Veneroida

Mysella bidentata (Montagu 1803)

Tellimya ferruginosa (Montagu 1803)

Turtonia minuta (Fabricius 1780)

Parvicardium ovale (Sowerby 1840)

Spisula elliptica (Brown 1827)

Macoma balthica (Linnaeus 1758)

Gari fervensis (Gmelin 1791)

Total for climatic regions .sbl: 19 (12.9\%)

Climatic regions: ..b.

Class Gastropoda

Subclass Heterobranchia

Order Heterostropha Chrysallida eximia (Jeffreys 1849)

Total for climatic regions ..b. : 1 (0.7\%)

Climatic regions: ..bl

Class Gastropoda

Subclass Prosobranchia

Order Archaeogastropoda

Patella vulgata Linnaeus 1758

Helcion pellucidum (Linnaeus 1758) 
Iothia fulva (Müller 1776)

Gibbula cineraria (Linnaeus 1758)

Gibbula tumida (Montagu 1803)

Skenea basistriata (Jeffreys 1877)

Order Neotaenioglossa

Littorina littorea (Linnaeus 1758)

Littorina tenebrosa (Montagu 1803)

Lacuna parva (Montagu 1803)

Hydrobia ulvae (Pennant 1777)

Hydrobia ventrosa (Montagu 1803)

Alvania punctura (Montagu 1803)

Cingula semistriata (Montagu 1808)

Onoba vitrea (Montagu 1803)

Rissoa albella Lovén 1846

Rissoa inconspicua Alder 1844

Rissoa membranacea (J. Adams 1800)

Rissoa parva (da Costa 1779)

Rissoa violacea Desmarest 1814

Caecum glabrum (Montagu 1803)

Bittium reticulatum (da Costa 1778)

Turritella communis Risso 1826

Aporrhais pespelicani (Linnaeus 1758)

Lunatia alderi (Forbes 1838)

Lunatia catena (da Costa 1778)

Order Heterogastropoda

Triphora adversa (Montagu 1803)

Cerithiopsis barleei Jeffreys 1867

Cerithiopsis tubercularis (Montagu 1803)

Epitonium clatbrus (Linnaeus 1758)

Epitonium turtonis (Turton 1819)

Aclis minor (Brown 1827)

Vitreolinaphilippii (Rayneval \& Ponzi 1854)

Order Neogastropoda

Hinia incrassata (Ström 1768)

Hinia pygmaea (Lamarck 1822)

Hinia reticulata (Linnaeus 1758)

Raphitoma purpurea (Montagu 1803)

Raphitoma linearis (Montagu 1803)

Subclass Heterobranchia

Order Heterostropha

Brachystomia eulimoides Hanley 1844

Odostomia scalaris MacGillivray 1843

Chrysallida decussata (Montagu 1803)

Chrysallida indistincta (Montagu 1808)

Chrysallida obtusa (Brown 1827)

Chrysallida spiralis (Montagu 1803)

Ebala nitidissima (Montagu 1803)

Eulimella laevis (Brown 1827)

Eulimella scillae (Scacchi 1835)

Ondina divisa (J. Adams 1797)

Ondina diaphana (Jeffreys 1848)
Odostomia acuta Jeffreys 1848

Odostomia conoidea Winckworth 1932

Odostomia turrita Hanley 1844

Odostomia albella Lovén 1846

Odostomia plicata (Montagu 1803)

Turbonilla crenata (Brown 1827)

Turbonilla delicata (Monterosato 1874)

Turbonilla lactea (Linné 1758)

Subclass Opisthobranchia

Order Bullomorpha

Acteon tornatilis (Linnaeus 1758)

Cylichna cylindracea (Pennant 1777)

Philine aperta (Linnaeus 1767)

Philine punctata (Adams 1800)

Order Anaspidea

Retusa truncatula (Bruguière 1792)

Retusa umbilicata (Montagu 1803)

Akera bullata Müller 1776

Class Bivalvia

Subclass Palaeotaxodonta

Order Nuculoida

Nucula nitidosa Winckworth 1930

Nucula nucleus (Linnaeus 1767)

Subclass Pteriomorpha

Order Mytiloida

Modiolula phaseolina (Philippi 1844)

Modiolus adriaticus (Lamarck 1819)

Modiolaria tumida (Hanley 1843)

Order Pterioida

Aequipecten opercularis (Linnaeus 1758)

Chlamys varia (Linnaeus 1758)

Palliolum striatum (Müller 1776)

Palliolum tigerinum (Müller 1776)

Pododesmus patelliformis (Linnaeus 1761)

Ostrea edulis Linnaeus 1758

Subclass Heterodonta

Order Veneroida

Lucinoma borealis (Linnaeus 1758)

Lepton nitidum (Turton 1822)

Acanthocardia echinata (Linnaeus 1758)

Parvicardium exiguum (Gmelin 1791)

Parvicardium scabrum (Philippi 1844)

Cerastoderma edule (Linnaeus 1758)

Cerastoderma glaucum (Poiret 1798)

Mactra stultorum (Linnaeus 1758)

Lutraria lutraria (Linnaeus 1758)

Spisula solida (Linnaeus 1758)

Spisula subtruncata (da Costa 1778)

Ensis ensis (Linnaeus 1758)

Phaxas pellucidus (Pennant 1777)

Angulus tenuis (da Costa 1778) 
Fabulina fabula (Gmelin 1791)

Donax vittatus (da Costa 1778)

Scrobicularia plana (da Costa 1778)

Abra alba (Wood 1802)

Abra nitida (Müller 1776)

Abra prismatica (Montagu 1803)

Chamelea striatula (da Costa 1778)

Clausinella fasciata (da Costa 1778)

Paphia aurea (Gmelin 1791)

Tapes decussatus (Linnaeus 1758)

Timoclea ovata (Pennant 1777)

Venerupis rbomboides (Pennant 1777)

Venerupis pullastra (Montagu 1803)

Mysia undata (Pennant 1777)

Order Myoida

Corbula gibba (Olivi 1792)

Saxicavella jeffreysi Winckworth 1930

Barnea candida (Linnaeus 1758)

Pholas dactylus Linnaeus 1758

Subclass Anomalodesmata

Order Pholadomyoida

Thracia phaseolina (Lamarck 1818)

Total for climatic regions ..bl: 107 (72.8\%)

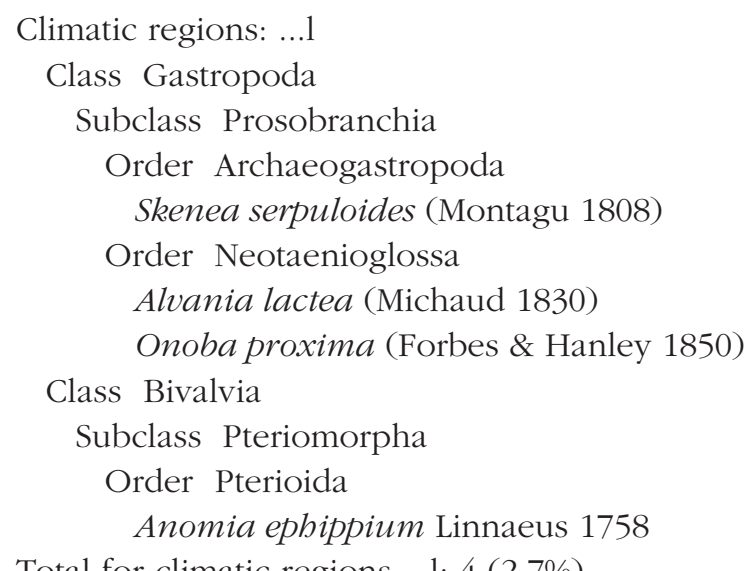

The Holocene Limfjord: 147 (59.5\%)

The mollusc species in the Limfjord region amount to 147 , and within this relatively high number only four purely Lusitanian species are found. Skenea serpuloides is known from recent waters in the British Isles and southward, Alvania lactea and Onoba proxima from the western coast of Britain and to the south, and Anomia ephippium also from the British Isles, although including the Orkney Islands and south to the Mediterranean. According to Jensen \& Spärck (1934), Anomia ephippium has often not been separated from Het- eranomia squamula. On the occurrences of Anomia ephippium and the three Lusitanian gastropods, which are all tiny and difficult species to work with in the subfossil state, the question may then arise whether much reliance should be put in these circumstances indicating that the subfossil Holocene fauna of the Limfjord region had a more Lusitanian affinity than is the case at present.

The next climatic group is the Boreo-Lusitanian, which is by far the largest, with 107 species, $72.8 \%$ of all the species recorded from this region. In the Limfjord region it is possible to distinguish between the recent fauna that arrived after the breakthrough at the Agger Tange in 1825, when the Limfjord again was established as a saltwater basin, and the older long stage before the Middle Ages and back to the transgression in the early Holocene.

The faunal record of the recent mollusc species from the Limfjord is an illustration of how fast a population can be established, although not studied from the very beginning (Spärck 1943, p. 78). The 85 species established there during the period of about 100 years picture recent immigration (Petersen 1986a, p. 223).

Already the early studies by Collin (1884) and Petersen (1888) demonstrated that within the subfossil Holocene fauna there was a certain number of mollusc species no longer known from the present fauna in the Limfjord or within the Danish waters at all. These deposits were called the Tapes beds by Petersen (1888, p. 56).

The Tapes species sensu Petersen (1888) include: Paphia aurea, Tapes decussatus, and Venerupis rhomboides, the last one has lately been recorded as part of the recent Danish fauna (Jensen \& Knudsen 1995).

The way to have a firmer basis for discriminating between the recent and the Holocene fauna in the Limfjord region would be to split the Boreal climatic region into the three zones: The High-Boreal, the MidBoreal and the Low-Boreal following the indications on distribution given in the chapter on the molluscan species, following Feyling-Hanssen (1955) in Fig. 4.

In this way it turns out that the recent Boreo-Lusitanian group, with a number of 51 , has $45 \%$ reaching to the north into the High-Boreal, 47\% the Mid-Boreal, and $9 \%$ the Low-Boreal zone. While the subfossil BoreoLusitanian group of 107 species shows 41\% reaching into the High-Boreal, 45\% the Mid-Boreal, and 14\% the Low-Boreal zone. There is, so to say, only a slightly higher affinity to more temperate southern waters for the subfossil molluscan fauna, meaning that a hypsothermal period is not clearly demonstrated in the ma- 
rine environment from the Limfjord.

In the case of the Limfjord region, it should be emphasised that we do have a special situation in connection with the living depths of certain species. Taking into consideration again the largest group of molluscs recorded from the Holocene Limfjord deposits the Boreo-Lusitanian group - 12 species have their main occurrence below the tidal zone, and 26 species out of the 107 species encountered occur at a deeper level. When this is seen from the fact that the collection of molluscs during the geological mapping has been done mostly in outcrops, and that the highest marine limit goes up to only about $5 \mathrm{~m}$ a.s.l. in this area (Mertz 1924), the palaeodepth reached cannot be as deep as figured on the basis of the general depth range of the recent molluscs in Danish waters. This was a point stressed by Nordmann (Jessen 1905, pp. 151-152) and clearly indicates a smaller living depth, found for the molluscs from the Limfjord region than from other regions in Denmark during the Holocene.

Such a difference in the habitat can still be observed on the beaches of the Limfjord, where inter alia the deeper-living mytilid Modiolus modiolus is found washed ashore quite commonly in quantities not seen elsewhere along the shores of Denmark.

The remaining climatic groups are the ones with a distribution extending into the Arctic or the Subarctic, some with a wide range reaching the Lusitanian or the Boreal zones to the south.

Here it should be pointed out that all of the species with their southern limit in the Boreal zone have been recorded also from the Low-Boreal sector, although Tridonta borealis is said to be rare in the North Sea, but is common in the Bælt Sea and Baltic regions.

From this it can be concluded that all the species recorded from the Holocene/recent Limfjord region could have coexisted in various habitats - except for the three purely Lusitanian species.

Several ${ }^{14} \mathrm{C}$ dates from the Limfjord region on molluscs from the Holocene reveal the immigration time of a few species (Petersen \& Rasmussen 1995a, table 1), although the actual number of dated shells of certain species are low. From the Atlantic: Mytilus edulis, Cerastoderma edule, Ostrea edulis, Arctica islandica, Spisula subtruncata, Corbula gibba, Scrobicularia plana, Acanthocardia echinata, and Venerupis pullastra. From the Subboreal: Lucinoma borealis, Tapes decussatus, and Paphia aurea. From the Subatlantic: Donax vittatus.

This is a function of the same species being used in many more datings, because specimens of these spe- cies have been present in a sufficient number or weight to allow a conventional ${ }^{14} \mathrm{C}$ dating of the whole assemblage or bed of molluscs. Therefore, also the other species present in the samples or stratum shall be considered dated, just as dating of certain levels in borings are taken into account (Petersen 1976, 1981, 1985b, 1986c; Rasmussen \& Petersen 1980).

In this way a far higher number of first occurrence of species can be demonstrated, still on the basis of absolute dates, as presented in Appendix 6.

For as many as 114 species out of the total number of recorded species (147) from the Holocene mollusc faunas in the Limfjord area first occurrence has been dated: 77 species dated to the Atlantic, 36 species to the Subboreal and one species to the Subatlantic.

In the Atlantic and the Subboreal the dominating climatic groups are the Boreal-Lusitanian species with 55 and 28 species, forming $71.4 \%$ and $77.8 \%$ respectively.

Two of the purely Lusitanian species which have been dated, Alvania lactea and Onoba proxima, appeared in the Subboreal.

The total number of species recorded from the Limfjord (147) constitutes 59.5\% of the subfossil Late Quaternary molluscs, which is much higher than seen in the inner Danish waters.

\section{The North Sea}

Climatic regions: asb.

Class Gastropoda

Subclass Opisthobranchia

Order Anaspidea

Retusa obtusa (Montagu 1803)

Total for climatic regions asb. : 1 (1.1\%)

Climatic regions: asbl

Class Gastropoda

Subclass Prosobranchia

Order Neotaenioglossa

Littorina saxatilis (Olivi 1792)

Lacuna pallidula (da Costa 1778)

Subclass Opisthobranchia

Order Bullomorpha

Cylichna alba (Brown 1827)

Class Bivalvia

Subclass Palaeotaxodonta

Order Nuculoida

Nuculoma tenuis (Montagu 1808)

Subclass Pteriomorpha 
Order Mytiloida

Musculus discors (Linnaeus 1767)

Subclass Heterodonta

Order Veneroida

Thyasira flexuosa (Montagu 1803)

Order Myoida

Mya truncata Linnaeus 1758

Hiatella arctica (Linnaeus 1758)

Total for climatic regions asbl: 8 (8.4\%)

Climatic regions: .sb.

Class Bivalvia

Subclass Heterodonta

Order Veneroida

Arctica islandica (Linnaeus 1767)

Order Myoida

Zirfaea crispata (Linnaeus 1758)

Total for climatic regions .sb. : 2 (2.1\%)

Climatic regions: .sbl

Class Gastropoda

Subclass Prosobranchia

Order Neotaenioglossa

Littorina obtusata (Linnaeus 1758)

Lacuna vincta (Montagu 1803)

Order Neogastropoda

Nucella lapillus (Linnaeus 1758)

Buccinum undatum Linnaeus 1758

Class Bivalvia

Subclass Pteriomorpha

Order Mytiloida

Mytilus edulis Linnaeus 1758

Order Pterioida

Heteranomia squamula (Linnaeus 1758)

Subclass Heterodonta

Order Veneroida

Mysella bidentata (Montagu 1803)

Tellimya ferruginosa (Montagu 1803)

Parvicardium ovale (Sowerby 1840)

Spisula elliptica (Brown 1827)

Macoma balthica (Linnaeus 1758)

Total for climatic regions .sbl: 11 (11.6\%)

Climatic regions: ..b.

Class Gastropoda

Subclass Prosobranchia

Order Neotaenioglossa

Cingula turgida (Jeffreys 1870)

Total for climatic regions ..b. : 1 (1.1\%)

Climatic regions: ..bl

Class Gastropoda
Subclass Prosobranchia

Order Archaeogastropoda

Gibbula cineraria (Linnaeus 1758)

Theodoxus fluviatilis (Linnaeus 1758)

Order Neotaenioglossa

Littorina littorea (Linnaeus 1758)

Lacuna parva (Montagu 1803)

Hydrobia ulvae (Pennant 1777)

Hydrobia ventrosa (Montagu 1803)

Onoba vitrea (Montagu 1803)

Rissoa albella Lovén 1846

Rissoa inconspicua Alder 1844

Rissoa membranacea (J. Adams 1800)

Rissoa violacea Desmarest 1814

Caecum glabrum (Montagu 1803)

Bittium reticulatum (da Costa 1778)

Turritella communis Risso 1826

Aporrhais pespelicani (Linnaeus 1758)

Lunatia alderi (Forbes 1838)

Lunatia catena (da Costa 1778)

Order Heterogastropoda

Triphora adversa (Montagu 1803)

Epitonium clatbrus (Linnaeus 1758)

Aclis ascaris (Turton 1819)

Aclis minor (Brown 1827)

Aclis walleri Jeffreys 1867

Order Neogastropoda

Hinia pygmaea (Lamarck 1822)

Hinia reticulata (Linnaeus 1758)

Subclass Heterobranchia

Order Heterostropha

Brachystomia eulimoides Hanley 1844

Chrysallida indistincta (Montagu 1808)

Chrysallida spiralis (Montagu 1803)

Eulimella laevis (Brown 1827)

Ondina diaphana (Jeffreys 1848)

Odostomia conoidea Winckworth 1932

Odostomia albella Lovén 1846

Turbonilla crenata (Brown 1827)

Turbonilla delicata (Monterosato 1874)

Turbonilla lactea (Linné 1758)

Subclass Opisthobranchia

Order Bullomorpha

Acteon tornatilis (Linnaeus 1758)

Order Anaspidea

Retusa truncatula (Bruguière 1792)

Retusa umbilicata (Montagu 1803)

Class Bivalvia

Subclass Palaeotaxodonta

Order Nuculoida

Nucula nitidosa Winckworth 1930 


\author{
Nucula nucleus (Linnaeus 1767) \\ Nucula sulcata (Bronn 1831) \\ Subclass Pteriomorpha \\ Order Pterioida \\ Chlamys varia (Linnaeus 1758) \\ Ostrea edulis Linnaeus 1758 \\ Subclass Heterodonta \\ Order Veneroida \\ Lepton nitidum (Turton 1822) \\ Acanthocardia echinata (Linnaeus 1758) \\ Parvicardium exiguum (Gmelin 1791) \\ Parvicardium scabrum (Philippi 1844) \\ Parvicardium minimum (Philippi 1836) \\ Cerastoderma edule (Linnaeus 1758) \\ Mactra stultorum (Linnaeus 1758) \\ Spisula solida (Linnaeus 1758) \\ Spisula subtruncata (da Costa 1778) \\ Ensis ensis (Linnaeus 1758) \\ Phaxas pellucidus (Pennant 1777) \\ Angulus tenuis (da Costa 1778) \\ Fabulina fabula (Gmelin 1791) \\ Donax vittatus (da Costa 1778) \\ Scrobicularia plana (da Costa 1778) \\ Abra alba (Wood 1802) \\ Abra nitida (Müller 1776) \\ Chamelea striatula (da Costa 1778) \\ Clausinella fasciata (da Costa 1778) \\ Paphia aurea (Gmelin 1791) \\ Tapes decussatus (Linnaeus 1758) \\ Timoclea ovata (Pennant 1777) \\ Venerupis pullastra (Montagu 1803) \\ Dosinia exoleta (Linnaeus 1758) \\ Dosinia lincta (Montagu 1803) \\ Order Myoida \\ Corbula gibba (Olivi 1792) \\ Saxicavella jeffreysi Winckworth 1930 \\ Barnea candida (Linnaeus 1758) \\ Subclass Anomalodesmata \\ Order Pholadomyoida \\ Cochlodesma praetenue (Pulteney 1799) \\ Thracia phaseolina (Lamarck 1818) \\ Total for climatic regions ..bl: 72 (75.8\%)
}

The Holocene North Sea: 95 (38.5\%)

From the North Sea region, 95 species have been recorded, and here no purely Lusitanian mollusc species has been found. Almost all the North Sea finds are recorded also from the Limfjord.

The Boreo-Lusitanian group in the North Sea region is also, compared to the Limfjord, by far the largest group, with 72 species.

In this group, only five species can be pointed out as not occurring in the Holocene of the Limfjord, viz.: Parvicardium minimum, Clausinella fasciata, Dosinia exoleta, Dosinia lincta, and Cochlodesma praetenue. Furthermore, Donax vittatus, as remarked earlier in the chapter on the mollusc species, this species does not belong to the Limfjord proper, but is recorded from old (Subatlantic) beach ridges once facing the Skagerrak. Today, this bivalve is bound to the exposed coast of Denmark, not penetrating into the inner Danish waters. The dated occurrences of this species in the North Sea area fall in the Subatlantic, when the present coastline of Jylland was developed (Petersen 1994a).

Donax vittatus has a distribution to the north up into the Mid-Boreal sector between Trondheim Fjord and Lofoten. The other Boreo-Lusitanian species in the North Sea region which are not in the Limfjord go as far north as the High-Boreal sector north of Lofoten. It is seen that the species not found in the Limfjord but in the Holocene North Sea are to be regarded not as newcomers showing any amelioration, but more probably as representing other conditions prevailing in the North Sea area than in the Limfjord, as seen in the case of Donax vittatus.

Parvicardium minimum is common only at depths of more than $30 \mathrm{~m}$. Clausinella fasciata is far from common in the inner Danish waters and, when occurring, is so only at depths of between 15 and $30 \mathrm{~m}$.

Dosinia exoleta and Dosinia lincta can be found from the intertidal zone and out to depths of 70 and $200 \mathrm{~m}$ respectively; these species have been recorded from the northern Kattegat, although the latter extends into the Øresund (Jensen \& Knudsen 1995).

The great similarity and the few differences found when the Holocene North Sea fauna is compared with the Limfjord record are explained in the recent study on the Agger Tange complex (Petersen 1994a, 1998). This study, being based on material from several vibrocores west of the Agger Tange complex, revealed that the Jydske Rev forms a continuation of the Limfjord complex $75 \mathrm{~km}$ further towards the west.

AMS dates of molluscs from this part of the North Sea and the oldest cored sections in the Agger Tange complex show that the marine record can be established from the Preboreal and up into the Subatlantic (Petersen 1985a).

The fauna dated from the older part of the Holocene is very similar to the Limfjord fauna and the younger fauna, containing only a few differences to 
Table 1. Boreo-Lusitanian group

\begin{tabular}{lrr}
\hline Time interval & Species & $\%$ \\
\hline The Preboreal-Boreal & 20 & 76.9 \\
The Arlantic & 23 & 85.2 \\
The Subboreal & 12 & 63.2 \\
The Subadantic & 5 & 62.5 \\
\hline
\end{tabular}

the Limfjord fauna, as indicated by the Dosinia species.

During the older stages of the Holocene, the Jydske Rev complex formed a landscape much the same as that of the present Limfjord, while in the younger part of the Holocene erosion has taken place and the present coastline of western Jylland developed.

The appearance of such molluscs as the Dosinia and Donax species must be connected with the new facies in the exposed coastal areas rather than indicating climatic changes.

The well-dated molluscs from the vibrocores in the North Sea and borings in the Agger Tange complex allow the fixing of a first appearance of most of the 95 species recorded from the North Sea region as seen in Appendix 6 (Petersen 1985a, 1994a).

The total number of recorded species from the Holocene North Sea is 95, forming 38.5\% of the subfossil molluscs from the Late Quaternary, which is less than recorded from the Limfjord, but out of this number 80 species have been dated with their first appearance. What is of special interest from this area is that the record also covers 26 dated species from the Preboreal-Boreal and furthermore 27 species from the Atlantic, 19 species from the Subboreal and eight species from the Subatlantic.

In all time intervals, the Boreo-Lusitanian group is by far the dominating part as shown in Table 1 .

As the Boreo-Lusitanian group in the North Sea constitutes the most temperate species, the Atlantic can be pointed out as having a slightly higher proportion of

Table 2. The climatic trend for the Holocene

\begin{tabular}{lrcrr}
\hline Climatic regions & \multicolumn{2}{c}{ Holocene subfossil spp. } & \multicolumn{2}{c}{ Recent spp. } \\
\hline asb. & 5 & $(0.7 \%)$ & 5 & $(5.4 \%)$ \\
asbl & 11 & $(6.0 \%)$ & 9 & $(9.6 \%)$ \\
.sb. & 3 & $(1.6 \%)$ & 0 & \\
.sbl & 19 & $(10.4 \%)$ & 7 & $(7.4 \%)$ \\
..b. & 3 & $(1.6 \%)$ & 7 & $(7.4 \%)$ \\
..bl & 136 & $(74.3 \%)$ & 64 & $(68.1 \%)$ \\
$\ldots$.. & 6 & $(3.3 \%)$ & 2 & $(2.1 \%)$ \\
\hline
\end{tabular}

warmer mollusc faunal element than the other periods.

In order to find the climatic trend for the Holocene, the climatic affinity of the recent species not found in the subfossil deposits is compared with that of the subfossil Holocene species (Table 2).

When the affinities to the climatic regions for the 183 Holocene subfossil species are compared with those of the 94 recent species that do not occur in the Holocene subfossil fauna, a slightly higher affinity to the more temperate regions for the subfossil species appears.

From the North Sea material it was concluded that the Atlantic has a slightly higher proportion of warmer elements than the other periods. So within the Danish realm the indication of amelioration, as seen from the molluscan material, points to the Atlantic.

\section{Vendsyssel}

Climatic regions: asb.

Class Gastropoda

Subclass Prosobranchia

Order Neogastropoda

Oenopota turricola (Montagu 1803)

Subclass Opisthobranchia

Order Anaspidea

Retusa obtusa (Montagu 1803)

Class Bivalvia

Subclass Heterodonta

Order Veneroida

Macoma calcarea (Gmelin 1791)

Total for climatic regions asb. : 3 (2.3\%)

Climatic regions: asbl

Class Gastropoda

Subclass Prosobranchia

Order Neotaenioglossa

Littorina saxatilis (Olivi 1792)

Lacuna pallidula (da Costa 1778)

Subclass Opisthobranchia

Order Anaspidea

Diaphana minuta Brown 1827

Class Bivalvia

Subclass Pteriomorpha

Order Mytiloida Musculus discors (Linnaeus 1767)

Subclass Heterodonta

Order Veneroida Thyasira flexuosa (Montagu 1803) 
Order Myoida

Mya truncata Linnaeus 1758

Hiatella arctica (Linnaeus 1758)

Hiatella rugosa (Linnaeus 1758)

Total for climatic regions asbl: 8 (6.0\%)

Climatic regions: .sb

Class Bivalvia

Subclass Heterodonta

Order Veneroida

Arctica islandica (Linnaeus 1767)

Order Myoida

Zirfaea crispata (Linnaeus 1758)

Total for climatic regions .sb. : 2 (1.5\%)

Climatic regions: .sbl

Class Gastropoda

Subclass Prosobranchia

Order Archaeogastropoda

Acmaea virginea (Müller 1776)

Order Neotaenioglossa

Littorina obtusata (Linnaeus 1758)

Lacuna vincta (Montagu 1803)

Skeneopsis planorbis (Fabricius 1780)

Onoba semicostata (Montagu 1803)

Order Neogastropoda

Nucella lapillus (Linnaeus 1758)

Buccinum undatum Linnaeus 1758

Subclass Heterobranchia

Order Heterostropha Omalogyra atomus (Phillippi 1841)

Class Bivalvia

Subclass Pteriomorpha

Order Mytiloida Mytilus edulis Linnaeus 1758

Modiolus modiolus (Linnaeus 1758)

Order Pterioida

Heteranomia squamula (Linnaeus 1758)

Subclass Heterodonta

Order Veneroida

Mysella bidentata (Montagu 1803)

Tellimya ferruginosa (Montagu 1803)

Turtonia minuta (Fabricius 1780)

Parvicardium ovale (Sowerby 1840)

Spisula elliptica (Brown 1827)

Macoma balthica (Linnaeus 1758)

Gari fervensis (Gmelin 1791)

Total for climatic regions .sbl: 18 (13.5\%)

Climatic regions: ..b.

Class Bivalvia

Subclass Heterodonta
Order Myoida

Mya arenaria Linnaeus 1758

Total for climatic regions ..b. : 1 (0.8\%)

Climatic regions: ..bl

Class Gastropoda

Subclass Prosobranchia

Order Archaeogastropoda

Helcion pellucidum (Linnaeus 1758)

Gibbula cineraria (Linnaeus 1758)

Gibbula tumida (Montagu 1803)

Order Neotaenioglossa

Littorina littorea (Linnaeus 1758)

Littorina tenebrosa (Montagu 1803)

Lacuna parva (Montagu 1803)

Hydrobia ulvae (Pennant 1777)

Alvania cimicoides (Forbes 1844)

Alvania punctura (Montagu 1803)

Cingula semistriata (Montagu 1808)

Onoba vitrea (Montagu 1803)

Rissoa albella Lovén 1846

Rissoa inconspicua Alder 1844

Rissoa membranacea (J. Adams 1800)

Rissoa parva (da Costa 1779)

Rissoa violacea Desmarest 1814

Caecum glabrum (Montagu 1803)

Bittium reticulatum (da Costa 1778)

Turritella communis Risso 1826

Aporrhais pespelicani (Linnaeus 1758)

Lunatia alderi (Forbes 1838)

Lunatia catena (da Costa 1778)

Order Heterogastropoda

Triphora adversa (Montagu 1803)

Epitonium clathrus (Linnaeus 1758)

Epitonium turtonis (Turton 1819)

Vitreolina philippii (Rayneval \& Ponzi 1854)

Order Neogastropoda

Neptunea antiqua (Linnaeus 1758)

Hinia incrassata (Ström 1768)

Hinia pygmaea (Lamarck 1822)

Hinia reticulata (Linnaeus 1758)

Cytharella coarctata (Forbes 1840)

Raphitoma linearis (Montagu 1803)

Subclass Heterobranchia

Order Heterostropha

Brachystomia eulimoides Hanley 1844

Odostomia scalaris MacGillivray 1843

Chrysallida indistincta (Montagu 1808)

Chrysallida obtusa (Brown 1827)

Chrysallida spiralis (Montagu 1803)

Ebala nitidissima (Montagu 1803) 
Eulimella laevis (Brown 1827)

Odostomia conoidea Winckworth 1932

Odostomia turrita Hanley 1844

Odostomia albella Lovén 1846

Odostomia plicata (Montagu 1803)

Turbonilla lactea (Linné 1758)

Subclass Opisthobranchia

Order Bullomorpha

Acteon tornatilis (Linnaeus 1758)

Cylichna cylindracea (Pennant 1777)

Philine aperta (Linnaeus 1767)

Philine punctata (Adams 1800)

Order Anaspidea

Retusa truncatula (Bruguière 1792)

Retusa umbilicata (Montagu 1803)

Akera bullata Müller 1776

Class Bivalvia

Subclass Palaeotaxodonta

Order Nuculoida

Nucula nitidosa Winckworth 1930

Nucula nucleus (Linnaeus 1767)

Subclass Pteriomorpha

Order Mytiloida

Modiolula phaseolina (Philippi 1844)

Modiolus adriaticus (Lamarck 1819)

Modiolaria tumida (Hanley 1843)

Order Pterioida

Aequipecten opercularis (Linnaeus 1758)

Chlamys varia (Linnaeus 1758)

Pecten maximus (Linnaeus 1758)

Pododesmus patelliformis (Linnaeus 1761)

Ostrea edulis Linnaeus 1758

Subclass Heterodonta

Order Veneroida

Lucinoma borealis (Linnaeus 1758)

Lepton nitidum (Turton 1822)

Kellia suborbicularis (Montagu 1803)

Acanthocardia echinata (Linnaeus 1758)

Parvicardium exiguum (Gmelin 1791)

Parvicardium scabrum (Philippi 1844)

Cerastoderma edule (Linnaeus 1758)

Laevicardium crassum (Gmelin 1791)

Mactra stultorum (Linnaeus 1758)

Lutraria lutraria (Linnaeus 1758)

Spisula solida (Linnaeus 1758)

Spisula subtruncata (da Costa 1778)

Ensis ensis (Linnaeus 1758)

Phaxas pellucidus (Pennant 1777)

Angulus tenuis (da Costa 1778)

Fabulina fabula (Gmelin 1791)

Donax vittatus (da Costa 1778)
Gari depressa (Pennant 1777)

Scrobicularia plana (da Costa 1778)

Abra alba (Wood 1802)

Abra nitida (Müller 1776)

Abra prismatica (Montagu 1803)

Chamelea striatula (da Costa 1778)

Clausinella fasciata (da Costa 1778)

Paphia aurea (Gmelin 1791)

Tapes decussatus (Linnaeus 1758)

Timoclea ovata (Pennant 1777)

Venerupis rhomboides (Pennant 1777)

Venerupis pullastra (Montagu 1803)

Dosinia exoleta (Linnaeus 1758)

Dosinia lincta (Montagu 1803)

Mysia undata (Pennant 1777)

Order Myoida

Corbula gibba (Olivi 1792)

Saxicavella jeffreysi Winckworth 1930

Barnea candida (Linnaeus 1758)

Pholas dactylus Linnaeus 1758

Subclass Anomalodesmata

Order Pholadomyoida

Thracia phaseolina (Lamarck 1818)

Total for climatic regions ..bl: 98 (73.7\%)

\author{
Climatic regions: ...1 \\ Class Gastropoda \\ Subclass Prosobranchia \\ Order Neotaenioglossa \\ Alvania lactea (Michaud 1830) \\ Trivia monacha (da Costa 1778) \\ Class Bivalvia \\ Subclass Pteriomorpha \\ Order Pterioida \\ Anomia ephippium Linnaeus 1758
}

Total for climatic regions ...1: 3 (2.3\%)

The Holocene Vendsyssel: 133 (53.8\%)

In the Vendsyssel region the mollusc species amount to 133 , nearly the same as recorded from the Limfjord region (147). However, some other species occur, although the grouping of species according to the climatic regions to which they belong is almost the same.

This is a very important fact considering the large number of species recorded from both regions and according to the conclusions drawn from the Limfjord material when compared to the recent fauna in the Limfjord, with only a slight difference between the climatic affinities of the subfossil and the recent mol- 
luscs, including the recent species which have invaded the Limfjord since 1825, but not recorded in the subfossil material.

The Vendsyssel fauna counts three purely Lusitanian elements, but they are far from common, and Alvania lactea and Trivia monacha are not typical for the former Vendsyssel palaeoenvironment.

Within the Boreo-Lusitanian group, only ten molluscs are new in the fauna compared to the Holocene of the Limfjord: Alvania cimicoides, Neptunea antiqua, Cytharella coarctata, Pecten maximus, Kellia suborbicularis, Laevicardium crassum, Gari depressa, Clausinella fasciata, Dosinia exoleta, and Dosinia lincta.

Nordmann (1904) states that the mollusc fauna recorded from the sites north of Frederikshavn have a distinct Lusitanian affinity. However, as seen above, only ten species are new to the Vendsyssel region compared to the Limfjord, and here four species reach into the High-Boreal sector (north of Lofoten), five species into the Mid-Boreal (between Lofoten and Trondheim), and only one, Neptunea antiqua, has its northern limit within the Low-Boreal sector (south of Trondheim and to the Channel). Therefore, the designation of the Dosinia fauna cannot be one of the special southern appearances. However, Nordmann also states that the same species in the Dosinia fauna are new compared to the Tapes fauna. This is true only for four species, viz. Laevicardium crassum, Neptunea antiqua, Trivia monacha, and Kellia suborbicularis, while Venerupis rhomboides, Lutraria lutraria, Gari fervensis and Hinia incrassata also occur to the south of Frederikshavn and in the Limfjord region. Furthermore, the characterising species of these beds - Dosinia exoleta - is now also recorded from the Subatlantic beds at a depth of $32.5 \mathrm{~m}$ in the North Sea, occurring together with, among others, Dosinia lincta.

Nordmann (1904, pp. 30-31) also argued for the Dosinia fauna to be a shallow-water assemblage and discussed in greater detail Dosinia exoleta, Venerupis rhomboides, Lutraria lutraria, Laevicardium crassum, Lucinoma borealis, Arctica islandica, and Neptunea antiqua. From the general information at hand on depth relations of these species (chapter on molluscan species), it appears that all except Neptunea antiqua can be found from the intertidal zone and out to various depths in deeper water, while Neptunea antiqua has a minimum depth of $15 \mathrm{~m}$.

Taking into account all the recorded molluscan finds from the Vendsyssel region, it appears that 84 species (63\%) can be found in the tidal-intertidal zone and 48 species (36\%) in water deeper than that. Therefore it cannot be characteristic of the Dosinia fauna that it is a shallow-water assemblage.

The new dates which have been used in the discussion of the Dosinia fauna date its appearance by the oldest date for the Dosinia exoleta, at 4240 B.P. (K5318; in Petersen 1991b).

\section{Skagen}

Climatic regions: asb.

Class Gastropoda

Subclass Prosobranchia

Order Neogastropoda

Oenopota turricola (Montagu 1803)

Total for climatic regions asb. : 1 (1.4\%)

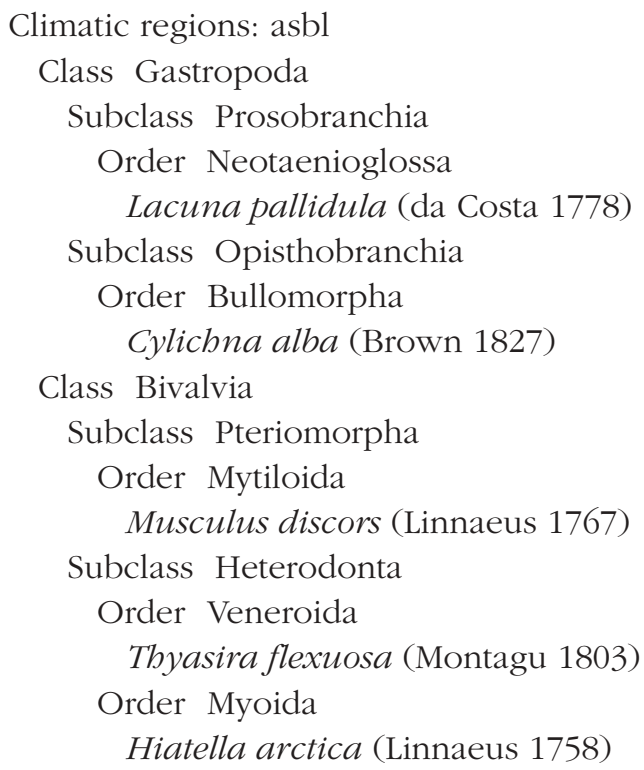

Total for climatic regions asbl: 5 (7.0\%)

Climatic regions: .sb.

Class Bivalvia

Subclass Palaeotaxodonta

Order Nuculoida

Nuculana minuta (Müller 1776)

Subclass Heterodonta

Order Veneroida

Arctica islandica (Linnaeus 1767)

Total for climatic regions .sb. : 2 (2.8\%)

Climatic regions: .sbl

Class Gastropoda

Subclass Prosobranchia

Order Neogastropoda

Buccinum undatum Linnaeus 1758 
Class Bivalvia

Subclass Pteriomorpha

Order Mytiloida

Mytilus edulis Linnaeus 1758

Order Pterioida

Heteranomia squamula (Linnaeus 1758)

Subclass Heterodonta

Order Veneroida

Mysella bidentata (Montagu 1803)

Tellimya ferruginosa (Montagu 1803)

Turtonia minuta (Fabricius 1780)

Garifervensis (Gmelin 1791)

Total for climatic regions .sbl: 7 (9.9\%)

Climatic regions: ..b.

Class Bivalvia

Subclass Heterodonta

Order Myoida

Mya arenaria Linnaeus 1758

Total for climatic regions ..b. : 1 (1.4\%)

Climatic regions: ..bl

Class Gastropoda

Subclass Prosobranchia

Order Neotaenioglossa

Hydrobia ulvae (Pennant 1777)

Barleeia unifasciata (Montagu 1803)

Onoba vitrea (Montagu 1803)

Rissoa albella Lovén 1846

Rissoa violacea Desmarest 1814

Bittium reticulatum (da Costa 1778)

Turritella communis Risso 1826

Aporrhais pespelicani (Linnaeus 1758)

Lunatia alderi (Forbes 1838)

Lunatia montagui (Forbes 1838)

Order Heterogastropoda

Epitonium trevelyanum (Johnston 1841)

Aclis minor (Brown 1827)

Polygireulima sinuosa (Sacco 1836)

Vitreolina philippii (Rayneval \& Ponzi 1854)

Graphis albida (Kanmacher 1798)

Melanella lubrica (Monterosato 1891)

Melanella alba (da Costa 1778)

Hemiaclis ventrosa (Jeffreys MS Fricle 1874)

Order Neogastropoda

Hinia pygmaea (Lamarck 1822)

Hinia reticulata (Linnaeus 1758)

Mangelia brachystoma (Philippi 1844)

Subclass Heterobranchia

Order Heterostropha

Chrysallida decussata (Montagu 1803)
Eulimella scillae (Scacchi 1835)

Odostomia conoidea Winckworth 1932

Odostomia umbilicaris (Malm 1863)

Turbonilla delicata (Monterosato 1874)

Turbonilla sinuosa (Jeffreys 1884)

Subclass Opisthobranchia

Order Anaspidea

Retusa truncatula (Bruguière 1792)

Retusa umbilicata (Montagu 1803)

Class Bivalvia

Subclass Palaeotaxodonta

Order Nuculoida

Nucula nitidosa Winckworth 1930

Nucula nucleus (Linnaeus 1767)

Subclass Pteriomorpha

Order Pterioida

Chlamys varia (Linnaeus 1758)

Ostrea edulis Linnaeus 1758

Subclass Heterodonta

Order Veneroida

Acanthocardia echinata (Linnaeus 1758)

Parvicardium minimum (Philippi 1836)

Mactra stultorum (Linnaeus 1758)

Spisula subtruncata (da Costa 1778)

Phaxas pellucidus (Pennant 1777)

Angulus tenuis (da Costa 1778)

Fabulina fabula (Gmelin 1791)

Tellina pygmaea (Lovén 1846)

Donax vittatus (da Costa 1778)

Abra alba (Wood 1802)

Abra nitida (Müller 1776)

Abra prismatica (Montagu 1803)

Chamelea striatula (da Costa 1778)

Timoclea ovata (Pennant 1777)

Order Myoida

Corbula gibba (Olivi 1792)

Saxicavella jeffreysi Winckworth 1930

Barnea candida (Linnaeus 1758)

Pholas dactylus Linnaeus 1758

Subclass Anomalodesmata

Order Pholadomyoida

Lyonsia norvegica (Gmelin 1791)

Cochlodesma praetenue (Pulteney 1799)

Thracia phaseolina (Lamarck 1818)

Total for climatic regions ..bl: 54 (76.1\%)

Climatic regions: ...1

Class Gastropoda

Subclass Prosobranchia

Order Heterogastropoda

Vitreolina collensi (Sykes 1903) 
Total for climatic regions ...1: 1 (1.4\%)

The Holocene Skagen: 71 (28.7\%)

From the Skagen boring, 71 Holocene species have been recorded.

The Boreo-Lusitanian group dominates with 54 species (76.1\%) of the Holocene mollusc species from the Skagen Well.

One purely Lusitanian species, Vitreolina collensi, has been found, while all the other species occur in the Boreal and to some extent the Arctic. In this way the Skagen Well material resembles that of other regions like the Vendsyssel, Limfjord and North Sea during the Holocene.

The Skagen Well material has all been recorded to certain stratigraphical levels, as seen in Appendix 6, so the climatic indications through time appear, but the number of molluscan species is very low. In the Pre-
boreal/Boreal, only three species have been recorded. This has been explained as a result of a deeper water where the echinoids dominate.

Higher up in the sequence, the number of molluscs increases -23 species in the Subboreal and 68 species in the Subatlantic.

Through the chronostratigraphical levels, the climatic regions of the Boreo-Lusitanian from the dominating one, and the purely Lusitanian Vitreolina collensi as mentioned above occurs in the Subboreal and Subatlantic. However, as already stated, the development of the facies in the Skagen Well during the Holocene does change the environment from the deeper-water facies with few molluscs through the bottom community with Turritella communis into the prolific shallow-water community. In this way the youngest part covering the Subboreal-Subatlantic is also by far the part with the highest species diversity.

\section{The environmental changes within the seven regions through the Late Quaternary evaluated by the molluscan communities met with in the seven stages}

The seven chronological stages which have been described according to their climatic affinities are seen in Fig. 102 and Fig. 103 covering the Eemian, the Early/ Middle Weichselian, the Late Weichselian, the Preboreal/ Boreal, the Atlantic, the Subboreal, and the Subatlantic.

In this way the climatic cycle during the Late Quaternary is demonstrated on the basis of marine mollusc species which indicate that the Eemian has by far the highest amount of the more temperate species, while the Holocene reached its maximum during the Atlantic, although only slightly more than the other stages within the Holocene, as already commented upon in the previous chapter.

It is generally accepted that the Eemian summer temperatures were higher - about $2^{\circ} \mathrm{C}$ above the present. With glaciers smaller than the present day, this means that the sea level was 4-6 $\mathrm{m}$ higher than today (Andersen \& Borns 1994, pp. 44-49). And as pointed out by Donner (1995, p. 39): "the submergence was clearly greater after the Saalian glaciation than after the Weichselian and possibly after the older glaciations".
Donner sees this in northern Europe as "a result of a comparatively great downwarping of the earth's crust during the extensive Saalian glaciation". The rebound since the last glaciation has come to an end within the Danish area (Petersen 1985c, 1991b). This means that the Eemian deposits, when found in Denmark in nonglacio-dislocated state, can be regarded as being in the original position related to sea level, although there might be some movements in relation to neo-tectonic activities, as mentioned earlier. In the light of the observations mentioned above, the seven regions will be discussed according to the environmental characteristics such as the climatic affinities for the molluscs recorded in Appendix 6 for each region, as appearing in Fig. 103. However, for the Holocene still as many as 130 species including the recent ones (95) not found as subfossil have not been dated to give their first appearance, see Fig. 102: Unknown arrival in Holocene. At the end of each of the seven stages the molluscan communities sensu C.G.J. Petersen will be presented in Tables 3-9. 